\title{
Mevlevilikte Müzik Felsefesi: Mesnevî́de Aşk, Mûsikî, Ney
}

\author{
Yalçın Çetinkaya*
}

Öz: Hak âşıkının Allah'a karşı duyduğu sevgiyi, heyecanı, hareket halinde, dönme halinde ifade etmesi, açığa vurması anlamlarına gelen semâ', Mevleviliğin müzik felsefesinde merkezi bir kavramdır. Böylece semâ'; dervişi kendinden, kendi varlığından kurtarmakta, manen Hak'ka yaklaştırmaktadır. Sanki benlik yumurtası içindeki civciv, yumurtayı delmeye çalışmakta; ten kafesinde mahpus ruh kuşu, göklere yükselmek için kanat çırpmakta; balçığa saplanmış kalmış olan ilahî emanet, balçıktan kurtulmak için hamle yapmaktadır. Semâ', musikinin tesiri altında kalarak gönülde Hakk'ı bulmak, heyecana kapılmak ve pervaneler misali dönmektir. Bu dönüş, yalnız bedenle dönüş değildir. Gönülle, ruhla, aşkla, imanla, maddi ve manevi bütün varlığı ile dönüştür. Bu dönüşte Hakk âşıkı, mevhum varlığından, kendi benliğinden kurtulur da Allah'da yok olur. Cüz'ün Küll'de kaybolması, bir zerrenin dönerek, titreyerek güneşe doğru yükselmesidir. Bu makalede Mevlevilikte semanın ve neyin yeri ele alınmakta ve aşk etrafında gelişen müzik felsefesi incelenmektedir.

Anahtar Kelimeler: Müzik, Semâ', Aşk, Sufizm, Zikr, Derviş.

Abstract: Sama' means to find Allah in one's souls under the influence of music, to feel excitement, and to whirl like moths. This whirling is not done just by bodily movements. It should be performed with the entire soul, spirit, love, faith, material and spiritual being. In this whirling the lover of Truth is saved from his imaginary existence and ego, and disappears in Allah. It is the disappearance of the part in the Whole and ascendance of an atom whirling towards the Sun. It is not even necessary to concentrate on the important place of sama' in Maulana's life and works. By looking into a few examples we can see how Maulana combined various trends in his understanding of sama'. The pre-eternal and post eternal Friend as mentioned in his quatrains manifests Himself dancing on the curtains of the heart so that He teaches the art of whirling during sama'. This sama' has a deep meaning; water of life gushes forth from the earth at the place where the beloved stepped his feet during his dancing. Music is universal like mysticism. Both have almost universal rules and come together through practices particular to themselves and both of them are distinguished from others by the practices of different people. Be it during a sama' or not there is such a special relation between the dervish and the music. Music completes a dervish's remembrance.

Keywords: Music, Sama', Love, Sufism, Zikr, Dervish.

* Yrd. Doç. Dr., İstanbul Teknik Üniversitesi Türk Mûsikîsi Devlet Konservatuarı

Illetişim: yalcincetinkaya60@gmail.com, ITÜ Türk Musikîsi Devlet Konservatuarı, ITÜ Maçka Kampüsü, 34357 Beşiktaş, İstanbul

Atıf(: Çetinkaya, Y. (2011). Mevlevilikte müzik felsefesi: Mesnevîde aşk, mûsikî, ney. Insan ve Toplum, 1 (2), 57-85. 


\section{Giriş: Mevlevilikte Müzik Felsefesi}

Mevleviliğin temel kitaplarından biri olarak Mesnevî́yi kabul edecek olursak Mevleviliği belirleyen temel dinamiklerin de Mesnevî kaynaklı olduğunu düşünebileceğimiz gibi; tasavvufun, Mevleviliğin tesisinden daha önceki dönemlerde, ilk sufilerin bazı düşünce ve görüşlerinin de Mevleviliği etkilediğini söyleyebiliriz. Mevleviliğin musiki (veya semâ') hakkındaki görüşlerinin temelinde Cüneyd ve Ruveym gibi ilk sufilerin, musiki (semâ') ile Bezm-i Elest arasında bir bağlantı kurmuş olmaları fikri aynen vardır. Cüneyd ve Ruveym'in bu düşüncelerinin tesirlerini, sadece Mevleviyye'de değil, Rifâiyye ve Halvetiyye'de de görebilmek mümkündür (Uludağ, 1992, s. 331).

Burhanu'l-Müeyyed tercümesinde şöyle bir rivayet vardır:

“Hz. Adem yeryüzüne indirilince üç yüz sene müddetle ağlamıştı. Cenâb-ı Hak ona; 'Niçin ağlıyorsun?' diye sorunca; 'Ya Rabbi ne cennetten ayrıldığım için, ne de cehennemden korktuğum için ağlıyorum. Arş-ı Âzâm'ın etrafında el ele vererek şevk ile raksedip: 'Padişahımız, mâlikimiz ne büyüktür. Mâlikimiz olmasa helâkimiz muhakkaktır. Madem ki sen Rabbimiz ve mabudumuzsun, bizden daha bahtiyar kim vardır? Sevgilimiz sensin, melce'imiz sensin, kim bize benzer" diyerek dolaşan yetmiş bin güzel yüzlü meleğe iştiyakımdan ağlıyorum' diye cevap vermişti. Bunun üzerine Allah; 'Başını kaldır, onları gör' buyurmuş. O da başını kaldırınca, Arş'ın etrafında bunların oynadıklarını, Cebrail'in ise bunlara başkanlık ettiğini, Mikail'in zâkirbaşılık yaptığını görmüş ve ağlaması kesilmişti."(Uludağ, 1992, s 333)

Bu izah göstermektedir ki Mevlânâ'dan çok evvel yaşamış olan Ahmed Rıfâî (H. 512-578 / M. 1118-1183) daha sonra Mevlânâ tarafından sık sık tekrarlanacak olan fikirleri aynen ifade etmiş, musiki ve semâ'ın ilahî, semavi, melekî, kutsi ve ulvi bir menşe'ye sahip olduğunu en açık şekilde beyan etmiştir. Esasen aynı hususlara ondan çok daha evvel, bütün sufilerin büyük bir evliya olarak gördükleri Seyyidü't-Tâife Cüneyd ile Ruveym de temas etmişlerdir (Uludağ, 1992).

Bir de musikinin, ruhun gıdası olduğuna dair tasavvufi görüşler vardır ve bu görüşler, tasavvufun ilk dönemlerine kadar uzanmaktadır. Tasavvuf ehlinin görüşlerine göre ruh gıdasını ele geçirdi mi (aldı mı), artık yüce makamına doğru yönelir ve bedenini idare etmekten vazgeçer. Bu görüşler içinde, Süleyman Uludağ'ın aktardığına göre Kelabâzî, Gazalî, Sühreverdî ve Kuşeyrî́nin görüşleri önemlidir ve musikinin ruhun gıdası olduğuna dair görüşleri benzerlik arzetmektedir (Uludağ, 1992, s. 334).

Mevleviliğin diğer bir dinamiği, "aşk"tır. Mesnevî̀nin ilahî aşk üzerine oturduğunu, her zaman için söylememiz mümkündür. "Aşk"ın Hz. Mevlânâ için taşıdığı önemi, başka eserlerinden de anlayabiliriz. Dîvân-ı Kebir adlı eserinde Mevlânâ şunları söylemektedir:

"Bizi aşkta ara, aşkı bizde. Gâh ben onu överim, gâh o beni över.

O sedef gibi denizler içinde bir ağzını açtı mı,

Ben ve biz denizini bir katre gibi içer, siler sömürür."(Rumi, 1943) 
"Aşkın derdi bütün dertlerden ayrıdır. Aşk, Allah sırlarının usturlabıdır. ${ }^{1}$ Aşk ister geçici olsun, ister gerçek; sonucu, bizi gerçeğe ulaştırır. Aşkı anlatmak için ne söylersem söyleyeyim, asıl aşk belirdi mi sözlerimden utanırım. Akıl, aşkı anlatmada, çamura saplanmış eşek gibi kalır. Aşkı, âşıklığı yine aşk anlatır. Güneşin varlığına delil, yine güneştir."(Rumi, 1973, s. 56-57).

Gölpınarlı'nın şerhine göre; irfan ehlince aşk, âşığın gözünden bütün varlıkları, gönlünden bütün istekleri sürer, çıkarır; âşığın gözünde sevgiliden başka bir varlık, gönlünde ondan başka bir istek bırakmaz. Bu, mecazi olmakla beraber, birliğe bir hazırlıktır. Bu yüzden de "Mecaz hakikatin köprüsüdür" demişlerdir. Aşk, şarap gibi insanın iç duygularını dışa vurdurur. Kötü duygulu kişi, engellerine düşman olur, cinayetlere kadar sürüklenir; iyi yetişmiş, iyi huyları tevarüs etmiş kişiyse insanlara, hayvanlara karşı merhamet duygularıyla duygulanır; sevgilinin baktığı, gördüğü, durduğu, gezdiği, sevdiği her şeyi sevmeye başlar (Rumi, 1973).

"Ben öyle bir aşka gark olmuşum ki, benden önce gelenlerin aşkları da benim aşkıma batmış, gark olmuştur, benden sonrakilerin aşkları da. Yemyeşil aşk bağının ne sonu vardır, ne ucu, ne bucağı. Orada gamdan, neşeden başka meyvalar var."(Gölpınarlı, 1963a, s. 110)

"Âşık, âşık ülkesinde ne söylerse söylesin, ağzından aşk kokusu duyulur. Din hukukundan bahsetse, ağzından yokluğa ait sözler çıkar; o sözlerden yokluk kokusu gelir. Kâfirlikten bahis açsa, o bahisten din kokusu duyulur. Şüpheye dair söz söylese adamakıllı, şüphesiz inancı anlatmış olur. Eğri söylese doğru görünür. O ne güzel eğridir ki, doğruyu bezer."(Rumi, 1973, s. 483)

Mevlânâ için aşk, ilahî sırrı keşfeden bir aletti. Her insan bu aleti usulüne uygun bir şekilde kullandığı takdirde, ebedî lezzeti yaşayabilirdi (Yaşar, 1985).

Mesnevî́nin "aşk" üzerine oturduğunu ileri sürdükten sonra, oradan neşet eden diğer şeylerle birlikte, Mevlevi musikisinin de aşktan neşet ettiğini söyleyebiliriz.

\section{Mesnevî'de Musikinin Temeli Olarak Aşk}

Mesnevî́nin "aşk" kavramı üzerine oturan bir eser olduğunu söyleyebiliriz. Bu aşk, kuşkusuz ilahî aşktır ve Mesnevî, bu aşkın detaylı bir anlatımı gibidir âdeta. Dolayısıyla, Mesnevî'den hareketle ve ondan ilham alınarak vücuda getirilen her şeyin, "aşk"ın bir ifadesi olduğunu söylemek herhâlde yanlış olmaz. Özellikle de Mevlevi musikisi için, tam anlamıyla bir aşk musikisidir demek de yanlış olmayacaktır. Çünkü Mesnevî "aşk"tır; ilhamını aşktan alan da ancak âşık kimsedir. Âşık kimsenin vücuda getirdiği her şey, "aşk"la ilgilidir, ilişkilidir, "aşk"a aittir veya "aşk"ın bir ifadesidir. Bunu, müzik tekni-

1 Usturlap: Gökteki yıldızların mevkiini ve Güneş'in yerini bu suretle de vakit tayin etmek için kullanılan, yarım daire şeklinde ve üstünde gök yuvarlağı resmedilmiş, akrep denen bir de müteharrik mili bulunan bir alettir. 
ği olarak örneklendirmek kolay olmayabilir. Ama belki müzikte, seslerin birbiriyle ilişkisi esnasında aşkı ifade ederken bir tür "aşk aralığı"nın tabii olarak kullanılığından söz etmek de mümkün olabilir. "Aşk, Mevlânâ için iki arzunun karşılaşması demektir: 'Eğer Cennet'i arzuluyorsan, Cennet de seni arzular'..."(Chevalier, 1993, s. 57).

Aşk, elbette fedakârlık istemektedir. Insanın sahip olduklarını terk etmesini gerektirir aşk. Allah için duyulan ideal aşk uğruna, gerektiğinde bütün dünya nimetlerinin feda edilmesi görüşü, aynı şekilde Kur'an'da da belirtilmiştir. Burada aşk, insanın sadece kendi iç dünyasında geliştirdiği bir duygunun adı olmayıp kesinlikle faaliyete yönelik olan bir haldir (Bu, Mevlânâ için de aynen böyledir). Öte yandan, yeni tasavvufi muhteva içinde hem tevekkülün hem de aşkın ağırlık noktaları önemli ölçüde değişmiştir (Fazlurrahman, 1981, s. 164).

Mevlânâ'ya göre aşk, Yaratıcının vasıflarındandır. İnsan neyi ve kimi severse sevsin; bu sevgi, gerçek varlığadır. Bu bakımdan o, insanı gerçek aşka götüreceği için geçici aşkı da hoş görmekte ve beşerî zaafı unutmamaktadır. Zaten ona göre hiçbir şey mutlak olarak hayr olmadığı gibi, mutlak olarak şer de değildir. Her birinin, yerinde faydası vardır, yerinde de zararı ve bilgi, bu bakımdan gereklidir. Adalet, her şeyi layık olduğu yere koymak, zulüm de layık olmadığı yere koymaktır. Yalnız Mevlânâ, gayrı tabii sevginin şiddetle aleyhindedir ve tasavvufun teviline kapılarak bu zevki hoş görenleri de kınar.

Mevlânâ'daki gerçek aşk, insân-ı kâmile karşı duyulan bağlılık veya kendi olgunluğunu onda görüştür ki cezbe hali geçince bu sevgi, dünyaya yayılır; bütün insanlara, hatta bütün canlılara taalluk eder; hayrı, güzeli, iyiyi, doğruluğu ve birliği hedef tutar ki Mevlânâ, hayatının her safhasında daima bu yüksek ve âlem-şümûl neşeye sahip olmuştur. Bu neşe, bazen merhamet, bazen bir görüş, bazen bütün bağlardan hür oluş, bazen ileri bir düşünce tarzında tecelli ettiği gibi bazen de kötüyü ve kötülüğü şiddetle tenkit mahiyetini alır. Mevlânâ'ya göre her şey sevgiliden ibarettir; âşık, bir perdedir. Yaşayan, ancak sevgilidir. Âşık ise, bir ölü... Aşka düşmeyen kişi, kanatsız kuşa benzer ve bu sevgi; insanı insan eden, hırstan, kibirden, varlıktan ve benlikten kurtaracak tek ilaçtır; insan onunla ferdiyetten kurtulur (Gölpınarlı, 1963a).

Çağımız düşünürlerinden Nureddin Topçu'ya (1998) göre, Mevlânâ'nın şahsiyetinde, şarkın büyük hakimi Sâdi ile Batı romantizminin zirvesi sayılan Goethe'yi birleşmiş buluyoruz. Gülistan'ın ağır başı kalender hakimi, Mesnevî'de muzdarip, haşin bir simaya bürünmüştür. Diğer taraftan Mesnevî́nin bir kuvvetli tarafı da Goethe'yi düşündüren muhteşem romantizmdir (Topçu, 1998, s. 115-116). Nureddin Topçu'nun bu kıyası oldukça ilginçtir. Buradan yola çıkarak Mevlânâ'yı, Doğu ile Batı'nın zirvelerini de aşan, ancak onları kendisinde birleştiren bir cevher olarak telakki etmemiz mümkündür. Mevlânâ'nın dünya görüşünün merkezinde, tabii ki, insan vardır. Onun ahlak felsefesi de insan temeline dayanıyor. Topçu'ya göre insanın diğer varlıklar arasındaki imtiyazIı durumu, aklın saltanatı ile bezenmiş olmasıdır. Aklın fonksiyonu ise onu, aşkın hudu- 
duna kadar götürmesidir. Akıl temeli tanıtır, ondan öteye gidemez. Akıl, bizi aşka teslim eder Topçu'ya göre, aşk da Allah'la birleştirir (Topçu, 1998, s. 117).

Mevlânâ'nın tasavvuf anlayışının temeli aşk, sevgi, semâ', vecd, cezbe ve istiğrak gibi mistik hallerdir. Sufiler, aşk ile arası olmayanlara ağır ithamlarda bulunurlar. Mesnevî ise aşk ile alışverişi olmayanların kanatsız kuş olduğunu ileri sürmektedir. O kimse, hakikat semalarında uçamayacaktır. Çünkü aşk, hakikat semalarında uçabilmektir. İnsan topraktan yaratılmıştı. Aşk, onu yükseltti. Yine topraktan ibaret olan dağa aşk sirayet edince dağ cezbeye gelerek raks etti. Cemâlullah'ı görmek isteyen Musa, Allah'ın bakışı ile nura gark olan Tur'a bakınca bir de ne görsün. Tur Dağı parça parça oluyor. O zaman Musa, aşkın bu şiddetine dayanamayarak düştü ve bayıldı. Aşkın ulaştırdığı vecd uykusundan uyanan sufi, bakıyor ki ortada ne âşık var, ne de aşk; yalnız maşuk var. Seven ölmüş, sevilen yaşıyor. Ruh, murada ermiştir. Kendisi ebedîleşmiş, ulûhiyet varlık halinde gözüken perdeyi üzerinden atmış, yalnız $O$ var. Fânî olan bütün hayaller, Allah'tan gayri bütün ruh hezeyanları ortadan kalkmış. Bir şey, yalnız bir şey var: O... Aşkın kanadında uçtuğu zaman, onun dünyası bambaşka oluyor. Her insanda aşkı görüyor ve Allah huzurundaymış gibi secdeye kapanıyor. Aşk anında büyük-küçük, yüksek-düşük, Müslüman-Mecusi hiçbir insanı birbirinden ayırmıyor. Çünkü hepsinde Allah'ı görüyor (Topçu, 1998).

\section{Aşk, Ahenktir (Armonidir)}

Halife Abdulhakim'in (1991) ifadesine göre; Mevlânâ'ya göre hiçbir şey aşksız hareket etmez ve âlem de bir aşk diyarıdır. Aşkla mukayese edildiğinde, kanun ve akıl ikinci dereceden fenomendir. Yalnız aşktır ki kendi kendini oluşturur, akılsa bu oluşumu gözden geçirerek hayattaki farklı tezahürlerin içindeki vahdeti tehdit eden unsurları ortaya çıkarır. Aşk, nihai hakikat olan Allah'ın mahiyetinin daha temel bir sıfatıdır. Batılı eleştirmenlere göre İslam, Allah'a karşı kayıtsız şartsız zoraki bir itaati içerir. Oysa bu tip bir itaat, seven Allah için söz konusu olamaz. Rahman, aşktan zuhur eder; Rabb aşktan dolayı besleyip kuvvet verir. Rahîm, aşktan dolayı bağışlar. Gerçekte Mevlânâ Celâleddin Rûmî ve sufilerin yapmış olduğu şey, aşkı sadece dine ve ahlaki hayata mahsus kılmadan anlamını genişleterek bütün mahlukata ve evrimci bir saik olarak aşka, evrensel (cosmic) bir önem vermektir. Kur'an'da Allah, kendisinin Rahman olduğunu ve Rahman'ın her şeyi kuşattığını söyler. Bir başka ayette, Cennet'in büyüklüğünün göklerin ve yeryüzünün tamamı kadar olduğunu, yani bütün âlemi kapsadığı söylenir. Bir gün gayrimüslim biri, Peygamber'e, şayet Cennet bütün varlık âlemini kuşatmışsa, Cehennem'in yerinin nerede olduğunu sordu. Peygamber, "Gün ışıdığında gece nerededir?" diyerek bununla Allah'ın aşkı tecelli ettiğinde, bütün âlemi kuşatacağını belirtir. Hegel, tabiatın ve aklın sürekli gelişimini mutlak sonsuzun zaman içinde diyalektik açılımı ile izah eder. Celâleddin Rûmî, hayatın ve tarihin dinamizmini diyalektik tez-antitez ve sentezle değil, evrensel aşkla açıklamaktadır. Benzer bir şekilde Rûmî, atomların gravitasyonel çekimleri ve maddenin kütleleri hakkında bir sezgiye sahiptir. Bunu mekanik dinamiklerle izah etmek yerine, çekici ve cezbedici dürtü olan aşkla açıklar. 
“Âlemde var olan tüm atomlar, âşıklar gibi birbirlerine doğru çekilirler, her biri aşkın manyetik çekimi ile eşine doğru yönelir. Gök cisimleri yeryüzünü kendilerine doğru bir kucaklaşma muhabbetiyle çekerler. Aşkın evrensel cazibesi neticesinde yeryüzü uzayda bir lamba gibi asılı durmaktadır.

Yeryüzünü bütün yönlerden çeken kuvvetlerin denkleştirildiği bir çekim oluşturarak ne onu uzağa fırlatmakta, ne de uzay boşluğuna düşürmektedir. Sanki o, yıldız feleği içinde bir demir parçasının hiçbir bağlantı olmadan asıı durduğu manyetik bir kubbe gibidir.

Rûmî'ye göre gök cisimlerini nebuladan yaratan aynı kuvvet, temelinde yaratıcılık olan aşktan dolayı yıldızları, gezegenleri, sistemleri ve daha da ileri giderek hayatı meydana getirir. Atomların birbirini çekmesi, neticede molekülleri oluşturarak daha ileri bir safhada evrimci bir dürtü ile önceki bitkisel hale gelip daha sonra hayvanî konuma gelen canlı organizmalar oluşturur. Hegel'e göre yaratılış, zıtların sentez olması sonucu oluşur. Fakat Mevlânâ Celâleddin Rûmî'ye göre görünüşteki zıtlıklardan kaynaklanan bu farklııık, aşkın cazibesi karşısında yok olur. Aşk Allah'tan kaynaklanır ve yaratıcı olan Allah'a yönelir. Bu nedenle yaratılış sürecinde safha safha ilerleyen aşk, her adımda yeni varlık formları oluşturur. Celâleddin Rûmî, gök cisimlerinin hareketlerinin salt mekanik olmadığını bilâkis aşkın sonsuz okyanusunda dalgalar olduğunu söyler. Şayet kozmik aşk var olmamış olsaydı, bütün mahlûkat donacak ve hiçbir şeyin anlamı kalmayacaktı. Aşksız hiçbir şey hareket etmez. (Abdülhakim, 1991, s. 53-56).

Çünkü Mevlânâ'ya göre aşk, Allah'ın bir vasfı olduğu için aynı zamanda sınırsızlıktır. Reynold A. Nicholson'a göre, Mesnevî'nin mistik ve ahlaki öğretisinin merkezinde "aşk" vardır. Yüzeysel veya dünyevi aşkı da ruhu safileştirebilecekken bu, "Bende benimle ilgili bir şey bırakmayan" aşkın gücü ne kadar yüksektir. Bu prensibi ilerleten şair, her kötülüğün evrensel açıdan iyi olduğunu; iradenin harmonisi içinde özgürlük / ihtiyaç antitezinin kaybolduğunu ve eski inançların da hiçbir değeri kalmadığını anlatmaktadır (Nicholson, 1995).

\section{Aşk, Hürriyettir}

Mevlânâ'ya göre Aşk, hürriyettir. Aşk olmadan hürriyet olmaz. Âşık kimse, hür kimsedir:

"Bağı çöz, hür ol ey oğul, niceye bir gümüşe, altına bağlanacaksın

Denizi bir testiye döksen ne kadar alır? Bir günlük su ancak.

Harislerin göz testleri dolmadı gitti;

sedef, elde ettiğini yeter bulmadıkça inciyle dolmadı.

Kimin elbisesi bir aşk yüzünden yırtıldıysa;

hırstan, ayıptan tamamen arındı o." (Rumi, 1973)

Hürriyet ile ilgili bu beyitleri, Abdülkadir Gölpınarlı şöyle şerhediyor:

"Hürriyet, dünya ve ahiret, madde ve mânâ kayıtlarından kurtulmak, benlik ve bencillikten halâs olmaktır. Yalnız dünya kayıtlarından kurtulmayı, işten güç- 
ten, çalışmaktan, kazanmaktan vazgeçmek, ahiret kayıtlarından kurtulmayı da ibadetten, sevap ümidinden geçmek gibi ters bir anlayışla anlamamak gerekir. Dünyadan kurtulmak, hırstan, nefsin dileklerinden halâs olmak, ahiret kayıtlarından kurtulmak da kulluğu Allah rızası için yapmak, emre, emir olduğu için uymak; nehyden, nehyedildiği için çekinmek, dünya dolusu mala mülke sahip olsa bile malı mülkü kendine kul etmek, onlara kul olmamaktır. Kur'an-ı Mecîd'de, Ensar hakkında; "Ve onların göçmesinden önce yurtlarını hazırlayıp orasını bir iman konağı haline getirenlere ve yurtlarına göçenleri sevenlere, onlara verilen şeylere karşı gönüllerinde bir ihtiyaç, bir istek duymayanlara, ihtiyaçları olsa bile onları kendilerinden üstün tutanlara gelince: Kim nefsinin hırsından, kıskançlık ve nekesliğinden geçerse gerçekten de o çeşit kimselerdir kurtulanların, muratlarına erenlerin ta kendileri" buyurulmaktadır. (Haşr Sûresi, 9. ayet). Hırstan, bencillikten kurtulmak ise, Mevlânâ'ya göre ancak gerçek aşkla mümkündür."(Rumi, 1973, s. 46-47)

Aşk, maddeten ve manen tam gelişmiş -ki bu yola gönül vermiş kişinin en büyük emelidir- kimselerin hayati bir güç ve huzur kaynağıdır. Bu mertebedeki aşk, her şeyin özüdür (hürriyetin de). Bir sufi için Yaratan, sevilecek yegâne varlık; Canan, en güzel varıık, aşkın ruha erişmek için ulaşılacak olan makamdır ve ona ulaşmak için sonsuz bir istek duyar. Gerçekte, ruhu kendisine cebrî bir cazibe ile çeken yegâne sevilen (maşuk), bunu eşsiz aşkı ve güzelliği ile yapar (Rice, 1964). Mesnevî́nin diğer bölümlerinde aşk ve hürriyet arasındaki ilişki vurgulanır. Mesela beşinci ciltte Mevlânâ, aşkını sadakatle sevdiğine sunup çaresizlik içinde kalmışken yapabileceği herhangi bir hizmet olup olmadığını soran bir âşıktan bahseder. Bunun üzerine sevilen cevap verir:

“Her şeyi yaptın ama, bir şeyi eksik bıraktın: Benliğinden vazgeçmek, benliğini öldürmek. Kök yerine dallarla uğraşıyorsun. Hâlen hayattasın, benliğinde yaşıyorsun. Gel, eğer hayatını ortaya koyan bir âşık isen, öl. Öl ve onun külliyetinde hayat bul."(Rice, 1964, s. 59)

Gerçek anlamda hürriyetin musiki ile, özellikle de "aşk" üzerine tesis edildiğini düşündüğümüz ve ileri sürdüğümüz Mevlevi musiki ile ne alakası olabilir? Şöyle düşünebiliriz: Hürriyet ancak gerçek aşkla mümkündür Mevlânâ'ya göre ve aşk da ancak gerçek manada hürriyetle. Bütün bağlardan kurtularak aşk mertebesine ve böylece hürriyete kavuşan bir insanın yapmış olduğu musiki de, gerçek anlamda aşkın, hürriyetin ifadesi olan bir musikidir ve Allah'tan başkası için yapılmış olması da mümkün değildir. Çünkü bu hürriyeti, ancak onun sayesinde elde edebilmektedir insan. Mevlevi musiki, gerçek anlamda aşkın ve hürriyetin musikisidir.

\section{Pythagoras'tan Mevlânâ'ya Musiki}

İslam düşünce dünyasında Pythagoras'ın tesirinde kalan düşünce ekolü, İhvân-ı Safâ'dır. Risaleler'inde Pythagoras ile aynı düşünceleri paylaştıklarını ve yollarının Pythagoras ve Pythagorasçı filozoflar ile aynı yol olduğunu, bu yolun da en doğru yol 
olduğunu açıkça belirtirken, önderlerinin de Pythagoras olduğunu açıkça ifade ederler (Karlığa, 1981).

"Iyi bil ki ey hayırlı ve şefkatli kardeşim, kıymetli kardeşlerimizin (ihvân-ı Safâ) mezhebi (tutumu, yolu) -Allah onları desteklesin- kainatta var olan tüm bilimlere (atf-ı nazar) etmek olduğundan... Fisagorsçu filozofların yaptığı gibi geometrik deliller ve sayısal örneklerle açıklamaktadır..."(Ihvân-ı Safâ, 1957, s. 48)

"Iyi bil ki ey hayırlı ve şefkatli kardeşim, Allah seni ve bizi kendisinden bir ruh ile desteklesin, feleklerin dokuz tabaka olması... ve bunun sayılara bağlı bulunmasında değerli hikmetler vardır. Beşerin anlayışı, onun bilgisinin derinliğine ulaşamaz. Fakat biz... Fisagorsçu filozofların görüşü uyarınca bu hikmetin bir cephesini anlatacağız..."(İhvân-ı Safâ, 1957, s. 48)

"İyi bil ki ey hayırlı ve şefkatli kardeşim... filozoflar, bilginler ve hakimler, varlıkların ilkeleri konusundan bahsetmişlerdir. Onlardan her bir topluluğa, diğerine doğmayan (bilemedikleri) sünuhat (doğuşlar, fikirler) doğmuştur. Ancak her grup, kendi fikirlerini belirtmek için çalışmış ise, "Varlıklar, adetlerin tabiatlarına göredir" diyerek, her hak sahibinin hakkını vermişlerdir. Bu risâlede işte biz bunu açıklayacağız. (Fisagorsçuların tuttuğu) bu yol, bizim kardeşlerimizin -Allah onları desteklesin- tuttuğu yoldur..."

Pythagoras'ın "aradığım ilmi buldum" diyerek musiki ilmine sarılmasına sebep olan hikâye, Mevlânâ'ya da -Ahmed Eflâkî'nin aktarmasıyla- şu şekilde atfedilir:

"Yine ahrârın büyüklerinden (Allah onlardan razı olsun) şöyle nakledilmiştir ki; bir gün Mevlânâ hazretleri Şeyh Selahaddin Zerkub'un (kuyumcu) dükkânı önünden geçiyordu. O sırada çekiç vuranların darbelerinin sesi mübarek kulağına gelerek semâ'ya ve raksa başladı. Büyük bir kalabalık toplandı. Şeyh Selahaddin hazretlerine Mevlânâ'nın semâ'a başladığı haberini verdiler. Şeyh çıraklarına, 'Elinizi çekiç vurmaktan alıkoymayınız ve altın yapraklar telef olacak diye korkmayınız' dedi. Kuşluk vaktinden ikindiye kadar semâ' oldu. Ondan sonra Mevlânâ 'Durdurunuz' diye buyurdu. Tam bu sırada gûyendeler yetişti. Mevlânâ semâ'a tekrar ciddiyetle başlayıp bu gazeli söyledi:

'O kuyumcu dükkânında bir hazine meydana çıktı.

Bu ne şekil, bu ne mânâ, bu ne güzel, bu ne güzellik ilâh.'(Ahmet Eflâkî, 1989, s. 115)

Bu rivayetten hareketle, Mevlânâ'nın da kuyumcuların çekiç seslerinden etkilendiği ve semâ' yapmaya başladığı belirtilerek, Pythagoras ile aralarında benzerlik kurulur ve hem Hz. Mevlânâ'nın, hem de Pythagoras'ın, musikinin kaynağını, çıkış yerini, semavi bir kaynakla izah ettikleri söylenir. Hatta Mevlânâ Mesnevî́de şunları söylemektedir:

"(Fakat padişahın) rebab sesini dinlemekten maksadı,

Iştiyak çekenler gibi O (ilâhî) hitabı hayal etmekti.

Zurna ve davul sesleri, bir parçacık o küllî neferin,

Kıyamet Günü'nde çalınacak olan Sûr'un sesine benzer. 
Hikmet sahibi kimseler 'Bu mûsikî nağmelerini (makamları)

gökyüzünün dönüşünden aldık' derler.

Halkın Tambur'la çaldığı, sesle söylediği ezgiler,

Gökyüzünün dönüşünün sesidir." (Rumi, 1973, s. 115).

Sufiler, musikiyi haram sayanlara, bununla karşı koyuyorlardı. Sufilerdeki yaygın inanca göre de musikiyi icat eden kimse, Hz. Süleyman'ın talebesi olan Pythagoras'tır. Feleklerin dönerken çıkardıkları sesleri işittikten sonra musiki ilminin öncülüğünü yapan Pythagoras, tasavvuf literatüründe de sıkça anılmaktadır (Ayvazoğlu, 1989). Bu teori, zaman zaman musiki ile astroloji arasında ilişkiler kurulmasına da sebep olmuştur. Risâle-i Mimâriyye'de musiki -astroloji ilişkisine ışık tutacak nitelikte, şu bilgiler mevcuttur:

“(...) makamlar da on ikidir. Sekizinci göğün on iki burcu olduğundan, makamları on iki kısım üzere koymuşlardı. On iki burç dedikleri; kuzu, boğa, ikizler, yengeç, arslan, başak, terazi, akrep, yay, oğlak, kova, balık. On iki makam dedikleri; Rast, Isfahan, Irak, Zirifkend, Büzürk, Zengüle, Rühavî, Hüseynî, Hicâz, Bûselik, Nevâ ve Uşşak'tır. Bundan başka dört unsur vardır ki "anâsır" dedikleri ateş, hava, su, toprak. Şube de dörttür. Şubeyi dört unsura göre koymuşlardır. Yegâh, Dügâh, Segâh, Çargâh. En aşağı mertebe Yegâh'tır, yukarı mertebe ise Çargâh. Dügâh ve Segâh, bu ikisinin arasındadır. Ve gezegenler de yedidir. Zuhâl, Müşteri, Merih, Şems, Zühre, Utarit, Kamer. Âvâze de yedidir. Zira âvâzeyi yedi gezegene göre koymuşlardır. Yedi âvâze dedikleri ise; nevruz, selmek, şehnaz, mâye, gerdaniye, hicaz ve geveşttir. Bundan başka, gece ve gündüz yirmi dört saattir. Terkîbât da yirmidörttür. Zira terkîbâtı yirmi dört saate göre koymuşlardır. Bir makamı ağaz edüp, yani başlayup başkasında karar edince, onda bir terkib elde edilir ve bu ilme de "Edvâr İlmi" ve "Mûsikî îlmi" derler. Bu ilmi yazıp düzenleyen, Hz. Süleyman'ın talebelerinden, hakîm Pythagoras'tır. Söz birliği ile yedi hakîmin en seçkinidir. Deniz dalgalarının vuruşundan, yani sığ yerlerde denizin talazından, birbirinin ardından gelüp taşra kıyıya vurmasından usûller bulup, yazup dizmiştir."(Gökyay, 1976, s. 125)

Mehmet Ali Ayni de feleklerin dönüşünden bir nağmenin hasıl olduğunu şu şekilde beyan etmektedir:

"Eski astronomiye göre sayıları yedi olan felekler, şeffaf kubbeler halinde birbirinin mihveri etrafında dönerler. Dönerlerken de, nehirden su çekip bağ ve bahçelere akıtan dolaplar gibi sesler çıkarırlar. Göklerin ve feleklerin dönüşünden hâsıl olan lâtif ve ruhnuvâz nağmeleri, lâhûtî mûsikîyi herkes işitemez. Bu nağmeleri, uzun bir çalışmadan ve gayretten sonra filozof Pythagoras işitmiş ve onun sayesinde mûsikî kaidelerini koymuştur."(Mehmed Ali Ayni, 1923, s. 151)

Görüldüğü gibi bazı kaynaklarda Pythagorasın görülen ve görülmeyen âlemleri seyrettiği, feleklerin yörüngelerinde dönerken çıkardıkları sesleri işittiği ve feleklerin ahengini dinlediği ileri sürülmektedir (Şehristani, 1153). Hâşim Bey de IIlm-i Edvâr Risâlesinde Pythagoras'ı ve onun musikişinas kişiliğini şöyle anlatır: 


\begin{abstract}
"Fisagor hekîmin ilm-i mûsikîde mahareti berkemâl olduğu, kuvve-i riyâziyye sebebi ile hâsıl olup, bu cihetle Sedâ-i Evdâ Ecrâm-ı Semâviyye'yi ve harekât-ı kevâkibi istimâ eyleyip derûnunda hıfz ve ittikân ve bu terkib üzere on iki makam, dört şube ve yirmi dört terkibi icâd eylediği kütüb-i muteberde mestûr ise de, Hoca Nasuriddin ve Ebu Ali Sînâ yirmi terkib, terkibatı mezkûrun üzerine zam ve ilave ederek kırk dörtte iblâğ etmişlerdir. Hekîm-i mezbûrun ihtirâı olan makâmât ki, seyr-i edvâr-ı kadîm üzere bunlardır: Rast, Irak, Isfahan, Zirekefend, Köçek, Büzürk, Zirgüle, Rehâvî, Hüseynî, Hicazb?uselik, Nevâ, Uşşak. On iki burca nisbetle on ikiye hasredildi. Ve bu yedi âgâze ki Heft Âgâze tabir eylemişler, bunlardır: Geveşt, Şehnâz, Selmek, Mâye, Nevrûz, Gerdâniye, Hisar, Seb'a-i Seyyâre'ye nisbet edip, Yegâh, Dügâh, Segâh, Çargâh yani çar şûbe tesmiye eylemişler."(Haşim Bey, t.y., s. 44).
\end{abstract}

Musikinin temellerini kurmaya çalışan ve Nikomakhos tarafından, sesler arasındaki ilişkiyi ilk defa keşfettiği belirtilen Pythagoras'ın, yine bazı İslam kaynaklarına göre musiki ile ilgili ilk bilgileri de Samos'lu bilgelerden öğrendiği rivayet edilir (Rosenthal, 1975). Buna bağlı olarak eski Yunan'ın, Pythagoras sayesinde aralıkları tanıdığı da ileri sürülür. Bugün sahip olunan müzik tekniğine ait bazı ifadelerin kaynağı, eski Yunan idi. (Fakat eski Yunan'a bu bilgiyi öğreten de Pythagoras'tır). Ton, diatonik sisteme; yarım ton, kromatik sisteme; çeyrek ton da anarmonik sisteme kaynaklık ediyordu denilebilir (Lavoix, 1955; Şehristani, 1153).

Tabii tüm bu özellikleriyle Pythagoras, musiki üzerine bilimsel kabul edilen ilk çalışmaları yapan kimse olmakla, musiki biliminin de babası kabul edilir (Pole, 1924). Musiki tarihinde, musikideki oranların kurallarını, titreşen cisim (vücut) efektlerinin uzunluklarının nasıl değiştiğini, verdiği müziksel tonların perdeleri arasındaki farkı izah eden ilk kişidir (McKinney ve Anderson, 1954). Bu arada Pythaoras'ın Hermetizm'den etkilendiği, Mısır'a giderek Memfis Mabedi'ne ulaştığı ve çok sıkı imtihanlardan sonra mabede kabul edildiği rivayet olunur (ibn Fâtik, 1106). Doğu'ya, Çin'e yaptığı geziden sonra Budizm'den etkilenmesi, Çin pentatonik müzik sistemini nakletmesi ve onu geliştirmesi gibi bilgilerden hareketle, Doğu'nun o zamanki bilgi ve hikmet rüzgârlarından da nasibini aldığı söylenebilir.

Nicholson'a göre, Pythagoras'ın en iyi bilinen teorileri, Müslüman felsefesi ve şiiri için neredeyse sıradandı. Basralı İhvân-ı Safâ'ya göre; gök kubbe döndüğünde, gezegenler ve yıldızlar hareket ettiğine göre Allah'ın (c.c.) övüldüğü, meleklerin ruhlarına zevk veren, aynen bizim ruhlarımızın bedenî dünyasında melodileri zevkle dinleyip keder ve üzüntülerimizden sıyrılmamı gibi, müziksel notaları olmalı. Bu melodiler olduğu kadar, cennet melodilerinin ekolarıdır ve bize cennet bahçelerini ve orada ikamet eden ruhların zevklerini hatırlatır ve ruhlarımız oraya uzanır (uçar) ve eşleri ile birleşirler (Nicholson, 1996). 


\section{Tasavvuf, Așk ve Musiki}

İslam dünyasında musikiye en fazla ilgi, genellikle tasavvuf ehli tarafından gösterilmiştir. İkinci asrın sonlarından itibaren musiki, semâ' adı altında tasavvufa girmeye başlamış ve İslam tasavvufunun belli başlı karakteristiği haline gelmiştir. Böylece bütün sufi ve tarikat mensupları tarafından benimsenen semâ', insanı Allah'a yaklaştıran ve yükselten dinî bir unsur olarak görülmüştür. Sufiler, musiki (gınâ) kelimesi yerine, özellikle semâ' kelimesini kullanarak o dönemde yaygın olan keyf ve nefs ehli ile karıştııılmaktan sakınmak istemişlerdir (Gazzali, 1979). Bunun yanında, semâ' kelimesini ölçülü ses ve hoş seda manasına gelen musiki yerine kullanmakla beraber, bu deyimin manasını genişleterek hoş olmayan sesleri de kapsayan bir mana vermişlerdir. Bunun sebebi, tabiattaki bütün seslerin özünde bir ahenk barındırıyor olmasıdır. Bu yüzden tasavvufta semâ' demek, musiki demek olmayabilir. Semâ', kulak vasıtasıyla işitilen bütün sesler demektir. Musiki, sadece semâ'nın özel bir bölümüdür. Hatta tasavvufta; sesle hiç ilgisi bulunmayan manevi hakikatler, sırlar, hikmetler, rüyetler ve müşahadeler de bir musiki (semâ')dir. Hatta tasavvufta sessizlik de bir semâ'dır (Âşıkpaşa'dan akt., Uludağ, 1992, s. 228-229).

Ayrıca sufiler semâ' kelimesini kullanarak ğına, elhan ve musiki deyimlerini kullanmamak suretiyle kendilerini dini bozmak ve yeni ibadetler uydurmakla suçlayan zahir ulemasının hücumlarına hedef olmaktan korumaya çalışmışlardır. Bu arada musiki ve raksa (semâ' ve vecd) eğlence ve oyun nazarıyla bakılmaması konusunda hassasiyet göstermişlerdir (Uludağ, 1992).

Süleyman Uludağ'a göre, semâ'dan bahsederken vecd'den de bahsedilmesi gerekmektedir. Çünkü vecd, semâ'nın semeresidir, vecdin semeresi de ya ölçülü ve ahenkli harekettir -ki mevzûn harekete raks ve tasfik adı verilir- veya ölçülü olmayan harekettir, ki buna da ıztırâb, sallanmak adı verilir. Vecd, semâ'nın meyvesi olan bir haldir, semâ' dinlemenin neticesi olarak Hak Teâlâ tarafından "gelen (vârid)" mânâdır, semâ' yapan bu manayı kendinde bulur (vecd). Bu buluşa "vecd" adı verilir (Uludağ, 1992).

Sufilerin semâ' ile "Elest bezmi" arasında bir münasebet kurmuş olmaları da oldukça dikkat çekici bir durumdur. Bu görüş, tasavvufta ve muhtelif tarikatler arasında hızla yayılmıştır. Bu münasebet, şu şekilde kurulmuştur: "Elestu bi-Rabbikum?" şeklindeki hitabı keyfiyetsiz ve şekilsiz olarak dinledikten sonra, o ilahî hitabı işitmenin zevki kalplerde yer tuttuğundan, Hazret-i Adem'in yaratılmasından ve zürriyetinin dünyaya gelmesinden sonra, bu gizli sırlar, zuhur eden halden dolayı bir nağme veya güzel bir kelime işittikçe, o eski ahitteki zevkli dinlemenin sebebiyle kalp uçacak hale gelir. Bunlar sevgi ve aşkları ezelden beri Allah için ve Allah ile olan, irfan sahipleridir. (...) Bundan dolayı musikide saklı olan gizli sırları idrak eder ve hazlarını alırlar. Şüphesiz ki "Elest" hitabını işitmiş olma sırrı, bütün canlıların tabiatında mevcuttur. Onun için her cins kendi tabiatına uygun bir şekilde semâ' eder, semâ'dan kendi himmeti nisbetinde hisse alır (Uludağ, 1992). 
Semâ', sufilere göre vecd ve trans halini destekleyip güçlendirir (Rice, 1964). Semâ', semâ' edenin Allah'a olan aşkını, kuvvetli arzusunu (şevkini) harekete getirir, çekiştirir ki, bundan da haller doğar. Bu haller, ateşleri ile kalbi yakar, onu pisliklerden temizler. Bu temizlikten sonra insanda 'muşâhede ve mukâşefe' hâsıl olur (Yazıcı, 1963) Vefatı, Mevlânâ'nın doğumundan iki yıl sonra vuku bulan (606 H. / 1209) Ruzbihan al-Baqli ise semâ'da çalgı çalıp şarkı söyleyen (Qawwal)'in güzel olmasını şart koşar ve semâ' meclisinde bulunan ariflerin kalplerinin rahatlandırılması için güzel koku, güzel yüz ve güzel ses gibi üç unsura ihtiyaç olduğunu kaydeder (Yazıcı, 1963).

Mevlânâ da Baqlî́nin görüşlerine yakın görüşlere sahiptir:

"Demek ki güzel ses, çalgı dinlemek âşıkların gıdasıdır,

Bu dinleyişte buluşmak, kavuşmak hayali vardır.

Gönüldeki hayaller, güzel sesle gelişir;

Hatta güzel ses yüzünden şekillere bürünür o hayaller.

Suya ceviz atanın ateşi nasıl yalımlandıysa,

Güzel seslerle aşk ateşi de parlar, yalımlanır" (Rumi, 1973)

\section{Mevlânâ ve Semấ}

Mevlânâ, âdeta kendini kaptırarak semâ' eder ve kendinden geçerdi. Sipehsalar'ın naklettiğine göre, semâ'ı âdeta bir ibadet haline getiren Mevlânâ, Şemsüddîn -i Tebrizî ile buluştuktan sonra semâ' etmeye başladı (Sipehsalar, 1312, s. 65) Nicholson'a (1996) göre Celâleddin Rûmî, Şems-i Tebrizî ile "tek ruhlu iki beden" olduklarını açıklamasından uzun bir süre önce, sufiler, mistik aşkın duygusal şeklini yeşertmişlerdi. Bu âşık ruhların birliğinde, tüm ayırıcı özellikler yok olur; aşkı duyanın ve duyulanın farklı kimliklerini birleştirdikleri aşkın birliği dışında, geriye hiçbir şey kalmaz. Rûmî, Şems'in isminin sanki "kendisi ve o" aynı olmuş gibi kullanırdı (Nicholson, 1996) Sultan Veled de İbtidânâme'sinde, Mevlânâ'nın Şems ile tanıştıktan sonra gece-gündüz semâ'da bağırıp çağırarak, yerlerde dönerek raks ettiğini, mutriblere altın ve gümüş verdiğini, nihayet çalıp söylemekten takat kalmadığını, bütün şehir halkının ona uyarak semâ'ya müptela olduğunu kaydetmektedir (Sultan Veled, 1312, s. 55).

Sipehsalar ise Mevlânâ'nın Şems-i Tebrizî'ye mülaki olmadan önce hiç semâ' etmediğini, Şems'in arzusu ile semâ'ya başladığını ve bunu ölünceye kadar hiç bırakmadığını, onu yol ve ayin haline getirdiğini naklettikten sonra, semâ'ın ruh üzerindeki tesirini izaha çalışır: Semâ', nefislerin istekleri ile meşgul oldukları için, halka haramdır. Allah talibi ve âşıklarına ise helaldir; zira bu suretle onlarda Allah'ı arama şevki ve halleri artar, Allah'tan başka bir şey gözlerine gözükmez. Ayrıca semâ' esnasındaki hareketlerini manalandırmaya çalışır; dönmek, Tevhid'i gösterir ki bu, muvahhid ariflerin makamı olup bu makamda arifler her cihette, mahbûb ve matlûbu görür ve döndükleri her tarafta bir feyze nail olurlar. Sıçramak ve oynamak, salikin nefsini teshir ve Tanrı'dan gayri her şeyi alt ettiğine delalet eder (Sipehsalar, 1312, s. 55). 
El sallamak (dast afşândan), visalin husulünden olan sevince, kemal mertebesine yönelmeyi, nefs-i emmâre askerini yenmeyi göstermektedir. Semâ' esnasında birini kucaklamak, ancak insanın kendi kendisinden tamamen geçtiği bir anda mübahtır (Sipehsalar, 1312, s. 55). Durma vaktinde kendisini kimin iç aynasında tam bir berrakIıkla müşahede ederse onu kucaklar, müşahede ettiği cemalinin hallerini bulur. Halkı semâ'a sürüklemek ve harekete teşvik etmek, sahv ehlinin makamı olup bu makamda gelen feyzi hazır bulunanların kalbine saçmak ve rahmeti hepsine şamil kılmak gayesi güdülür. Tevazu ve secde ise kulluk makamından ibarettir. Semâ'da midenin boş olması şarttır (Sipehsalar, 1312, s. 55).

\section{Kâinatta Her Şey Dönüyor}

Görülüyor ki Sipehsalar'da Mevlânâ'nın Şems'in teşviki ile ayin (resm, adet, kanun) ve tarîk (yol, adet) haline getirdiğinden bahsedilen semâ'ın icra şekli hakkında, sadece kol ve ayak hareketleri ile dönmeden bahsedilmekte ve fakat bunların tarifleri verilmemektedir. Sadece bu semâ' fikrinin, kâinattaki her şeyin döndüğünden hareketle ortaya çıktığı ve gezegenlerin dönüşlerinin, dönerek semâ' yapma konusunda Mevlânâ'ya fikir verdiği rivayet edilmektedir. Hoşa giden veya manalı bir ses, Mevlânâ'yı semâ' ettirmeye kâfi gelirdi. Sokakta, pazarda, Meram mescidinde, ılıcada, değirmende, Konya meydanında semâ' ederdi Mevlânâ. Semâ' için önce kabiliyet şart koşulur, fazla semâ'dan Konya halkının alttan alta semâ' aleyhinde bulunduklarından da şikâyet ederdi (Ahmet Eflâkî, 1989).

Mevlânâ'nın semâ'ında ve hissiyatında "aşk"ın temel kavram olduğunu belirtmiştik. Aşk, onun için her şeydir. Mevlânâ'da ve Mevlevilikte her şeye cezbe ve aşkla ulaşıldığı düşüncesi vardır. "Aşk olmayınca meşk olmaz" atasözü, bir Mevlevi'nin her işinde kılavuzdur (Gölpınarlı, 1963b).

Mevlânâ, Mektuplar'da şöyle yazar:

"Ustan aşktır senin; oraya varınca,

Zâtı o, hal diliyle sana söyledi mi, dediğini yap."

"Fark vardır candan kopup gelen aşkla,

İple bedene bağlanan sevgi arasında."

"Aşk ehlini ağırlamak keremdendir;

Aşk ümmeti, ümmetlerin en arığıdır." (Rumi, 1963)

Mevlevi semâ'ı, dışarıdan bakıldığında ilginç gelebilecek bir hareket biçimidir. Nitekim bu konuda epey açıklamalar getirilmeye çalışıımıştır.

"Bir Mevlevî semâ'ı esnasında dervişlerin dönmesi, aynı şekilde merak konusu olan bir uygulamadır. Dönmenin arkasındaki gerçek ise, dış bünyenin boşa ve dönmeye bırakılması, aynı zamanda iç bünyenin ve onun yerleşmesinin 
sabit kalması ve güçlenmesidir, aynen hızla dönen tepenin merkez çekirdeğinin tamamen sabit kalması gibi. Dönmek, ağaçlar etrafında dönerek Mevlânâ Celâleddin-i Rûmî tarafından geliştirildi ve sabitleştirildi. Dışa doğru dönmek, içe doğru hareketsizlik gibi iki zıt gerçeği birleştirerek tek bir noktayı uygulamada başardı. Dönerken, dikkat içe doğru (kalbe doğru) verilir ve Allah (c.c.)'a göre, sanki dışa doğru verilir. Dönen kişi bir süre sonra uyuşur." (Haeri, 1997, s. 64)

Sipehsalar, nağmeli ses ile semâ' etmenin, âşıklarda derin tesirler bıraktığını ifade ederek bunun sırrını şu şekilde açıklar:

“Nağmeli ses, âşıklara şundan dolayı hoş gelir: Onlar 'Elest Meclisi'nde, rûhânî güzel seslere alışmışlar ve onun verdiği boşluğa kulak vererek yetişmişlerdir. Nefs âlemine ve vücudun bulanıklığına yakalanmış, rûhânî âlemden uzak kalmış oldukları bu günde ise, o güzel seslerden birazcık kulaklarına gelince, hüzünlü olan gönülleri şevklerinin fazlalığından çırpınır, coşar ve bedeni de ona uyarak harekete getirir. Semâ' esnasında hakikati bilenlerden hasıl olan hareketlerin hepsi, bir nükte ve gerçeği gösterir. Nitekim dönmek, tevhide işarettir. Ve bu, belirleyen (muvahhid) âriflerin makamı olup, bunlar o halde istenen ve arananı her tarafta görürler; döndükleri her tarafta onun taşmasından nasiplerini alırlar." (Sipihsalar, 1977)

Semâ' esnasında yapılan bazı davranış ve hareketlerin de özel manaları vardır. Sipehsalar, onları şöyle izah ediyor: Sıçramak ve ayak vurmaya (Pây kûften) gelince; bu iki hareket iki şeyi işarettir: Sıçramak, şevkin fazlalığından yüksek âleme ulaşmadır. Ayak vurmak ise salik, o halde nefsini hükmü altına alıp Allah'tan başka her şeyi himmetinin ayağı altında eziyor. Kol açmak ise birkaç şeye işarettir: 1. Vuslat şerefinden hasıl olan sevince ve kemal derecesine yönelmeye 2. Nefs-i emmâre ordusunu yenmeye işarettir ki büyük cihat (cihad-ı ekber) bundan ibarettir. Semâ' esnasında bir azizi kucaklamak ve birlikte semâ' etmek şu zaman vaki olur: Derviş tamamılla kendisinden yok olur, semâ'a kalktığı zaman topluluğun içinde, kimin aynasında kendisini tam bir berraklık ile görürse, o azizi kucaklayıp kendi cemalinin hayali ile o azizle aşk oyunu oynar. Halkı semâ'a sürüklemek, harekete teşvik etmek, ayık halkın hali olup feyzi bütün hazır bulunanların düşüncesi üzerine sıçrar ve Allah'ın merhametini hepsine yayar. Semâ'da alçakgönüllülük göstermek ve secde etmek, ibadet halinden (makamından) ibarettir; zira semâ' eden, semâ'da ayakta durma, eğilme ve yere kapanma da sevilene (Allah'a) kulluk eder. Kırk yıl Mevlânâ'nın hizmetinde bulunan Sipehsalar'ın(1997) Mevlânâ'dan rivayet ettiğine göre, semâ' ehlinin hareketi ve durması, eğlence ve boş şeyler üzerine değil, ciddiyet üzerine kurulmuştur.

Sipehsalar, Mevlânâ'dan semâ' ile ilgili şöyle dediğini rivayet eder:

"O halde semâ' âşıkların gıdası oldu.

Zira onda (sevgili ile) birleşmenin hayali vardır." (Sipihsalar, 1977, s. 72)

Semâ', herkesin yapabileceği bir şey değildir. Özellikle halkın semâ' yapması uygun değildir. Semâ' yapmaya Mevlânâ'yı teşvik eden Şems-i Tebrizî'dir: 
"Semâ' yap, zira istediğini ancak semâ'da bulabileceksin". Semâ', kendi nefislerinin istekleri ile meşgul oldukları için halka haramdır. Halk, semâ' ettiği vakit yerilen ve tiksinilen haller artar; boş şey ve aşırı sevinçten dolayı (nâhoş) hareket ederler. Hiç şüphesiz böyle bir zümreye semâ' haram olur. Halbuki Allah'ı arayan ve ona âşık olan ve semâ'da aşk ve şevki artan, o esnada Allah'tan başka gözlerine bir şey görünmeyen topluluğa semâ' helâl olur." (Sipihsalar, 1977, s. 72).

Hazreti Mevlânâ kendisinin, Allah âşıklarının veya dindar muhiplerinin gördüğü bedende olmadığını söylemiş ve "Ben belki de müritlerin 'Allah! Allah! diye bağırdıkları zaman tattıkları mutluluk ve neşeyim, bu nedenle bu mutluluğun tadını almaya bakın" demiştir. Bir defasında yukarılarda uçan bir kuş olduğunu ve göklere ulaşmadığını; evin çatısına kadar yükseldiğini ve sonra kaçtığını söyler. Yani bu kuş, derviş olan insanla birliktedir ve bu insan normal insanlara göre çok daha üstün bir zat oluncaya ve normal varlıkların çok daha üstündeki bir mertebeye varıncaya kadar tam bir derviş olamaz. Derviş, dünyadaki keder ve üzüntülerden uzaklaşır ve tüm sıradan insan duygularından sıyrılır (Brown, 1927, s. 251).

İste semâ', dervişe bu yolu açar. Mevlevilerde semâ', aşk ve cezbeyi meydana getirmek için bir vesiledir ve her Mevlevi mutlaka semâ' etmesini de bilir (Gölpınarlı, 1953, s. 387).

\section{Mevleviliğin Müzik Felsefesinin Temellendiği Illk On Sekiz Beyit}

“Dinle, bu Ney nasıl şikâyet ediyor; ayrılıkları nasıl anlatıyor.

Diyor ki: Beni kamışlıktan kestiklerinden beri feryadımla erkek de ağlayıp inlemiştir, kadın da.

Ayrılıktan şahrem şahrem olmuş bir gönül isterim ki iştiyak derdini anlatayım ona.

Aslından uzak kalan kişi, gene buluşma zamanını arar.

Ben her toplulukta ağladım, inledim; iyi hallilerle de eş oldum, kötü hallilerle de.

Herkes kendi zannınca dost oldu bana; içimdeki sırlarımıysa kimse aramadı.

Benim sırrım, feryadımdan uzak değil; fakat gözde, kulakta o Işık yok.

Beden candan, can da bedenden gizli değil; fakat kimseye canı görmeye izin yok.

Ateştir Ney'in bu sesi, yel değil. Kimde bu ateş yoksa, yok olsun o kişi.

Aşk ateşidir ki Ney'e düştü; aşk coşkunluğudur ki şaraba düştü. Ney, bir dosttan ayrılana eştir, dosttur; perdeleri, perdelerimizi yırttı gitti. 
Ney, kanlarla dolu bir yolun sözünü etmede; Mecnun'un aşk

hikâyelerini anlatmadı.

Ney gibi bir zehri, Ney gibi bir panzehiri kim gördü?

Ney gibi bir solukdaşı, bir iştiyak çekeni kim gördü?

Bu aklın mahremi, akılsızdan başkası değildir; dile de

kulaktan başka müşteri yoktur.

Gamımızla günler geçti, akşamlar oldu; günler yanlışlarla

yoldaş kesildi de yandı gitti.

Günler geçip gittiyse, de ki: Geçin, gidin, pervamız yok.

Sen kal ey dost, temizlikte sana benzer yok.

Balıktan başka herkes suya kandı; rızkı olmayanın da günü

uzadıkça uzadı.

Ham hiçbir pişkin, olgun kişinin hâlini anlayamaz;

öyleyse sözü kısa kesmek gerek vesselâm."(Rumi, 1973, ss. 26-27).

Bu on sekiz beyitte, birinci planda 'Ney' vardır. Şikâyet etmektedir; ayrılıkları anlatmaktadır: "Kamışlıktan kesildim kesileli feryat etmedeyim; erkek kadın herkes feryadıma uymada, ağlayıp inlemededir. Aslından uzak düşen, elbette buluşma çağını arar. Her toplumda ağladım, inledim; herkesle eş dost oldum; herkes kendince bana dost oldu; ama içimdeki sırlarımı kimse araştırmadı." demektedir. Mevlânâ, neye aşk ateşinin düştüğünü, hakikat şarabını aşkın coşturduğunu söyler: "Ney gibi hem zehir hem panzehir olan, onun gibi solukdaş kesilen yoktur; o, kanlarla dolu bir yolu bildirmede, Mecnun'un hikâyelerini anlatmadadır." der. Sonunda da ham kişinin pişkin, olgun kişinin halini anlayamayacağını, sözün kısa kesilmesi gerektiğini söyleyip bu on sekiz beyti bitirir.

Eski şârihlere göre, buradaki ney, "İnsân-ı Kâmil"dir. O, birlik kamışlığından kesilmiştir. Kendi varlığından geçmiş, gerçek varlıkla var olmuştur. Ondan çıkan her ses, Allah iradesini bildirir; onun ihtiyarı, Allah ihtiyarıdır. Fakat görünüşte sıfatlarla, fiillerle kayıtlıdır; bu bakımdan "Itlak" âlemini özler. Daha doğrusu da onun bu özleyişi bir cilvedir, kendi kendisine bir nazdır. Nitekim;

Men zı cân-ı can şikayet mikunem

Men neyem şaki rivayet mikunem,

yani, "Ben canın canından şikâyet etmedeyim; ama gerçekte şikâyetçi değilim, rivayet etmedeyim ancak." buyurur (Rumi, 1973, s. 348).

Mana bu yöne götürüldü mü, ney ancak bir mecazdır. Mesnevî̃yi başka bir tarzda anlamak iddiasına düşenlere göreyse bu beyitlerdeki ney, maddi neydir. Manaları bu yöne çevirmek tamamıyla yanlıştır (Ateş, 1953).

İlk iddialar mı doğrudur, yoksa bu son iddia mı? Bu hususta Mevlânâ diyor ki: 
"A güzel sesli Ney, gönüller almadasın, hoşsun, güzelsin; sıcak sıcak nefes vermedesin, soğuk havaları silip süpürmedesin. İçinde ne boğum var, ne bir şey; bomboş. Dertlere düşmüş, perişan olmuş gönülden, candan derdi, elemi alma$\mathrm{da}$, onları da kendine döndürmedesin. Herkesin, sevgilisine uygun bir resimdir, yapıyorsun; okuma yazma bilmiyorsun ama içyüzden bir ressamsın âdeta. Ey tüm gerçeklerin şekli, sureti, hangi perdedesin sen? Neyin nağmeleri arasından bir baş göster; şekerler gibisin sen çünkü. Gözün dokuz olmuş sanki; can da on kulağını sana vermiş; altı yana da üfle nağmelerini; altı yana da bildiksin, tanıdıksın sen. Ey başı kesilmiş kamış, dilsiz dudaksız sırlar söyle; boğazdan tattığın soluğu, halka da bir hoşça tattır. Ney'e aşk ateşi düştü, âlemi bir dumandır kapladı; çünkü sesin aşk sesi; aşk sesini duyurmadasın, ateşlisin sen. Aşkınla Leyla'nın Mecnun'un sırlarını okşa; gönle ne tatsın sen, cana ne huzur. Hâsııı soluğunda Tebriz'den bir koku var; güzelliğinle, alımınla nice gönüller kapmadasın sen."(Rumi, 1943, s. 446).

Âdeta Mesnevî́nin on sekiz beytinin bir başka tarzda ifadesi olan bu gazelde ney, gönüller almada. İçinde ne boğum var, ne bir şey. Herkesin sevgilisine uygun bir resim yapıyor. Tüm gerçeğin şekli o. Altı yana da bildik. Düştüğü ateş aşk ateşi. Verdiği ses, aşk sesi. Leyla'nın, Mecnun'un sırlarını okşayabilir; soluğunda Tebriz'den bir koku var. Açıkça görülüyor ki maddi ney, mana âleminin tercümanı oluyor; bir sembol kesiliyor.

Yine Mevlânâ bir gazelinde, şöyle diyor:

Metaz iy dil sû-yı deryâ-yı nârî

Ki mitersem ki tâb-ı nâr nârî

Vücudet ez ney-o dâred nevâyî

Zi ney her dem nevâ-yı nov bizârî

Neyistânet nedâred tâb-ı ateş

Ve gerçi tu zeni şehri berârî (Füruzan-fer, 1340).

Başka bir gazelinde ise:

Eğer hâli şevi ez hiş çün ney

Çü ney pur ez şeker akende bâşî, (Füruzan-fer, 1340).

Bir başka gazelde de deniyor ki:

Merâ her lehze kurbânest cânî

Tura her lehze der bend-i gumânî

Du çeşm-i tu beyân-ı hâl-ı nem bes

Ki ruşenter ezin nebved beyânî

Cihan çün ney hezârân nâle dâred

Ki yek ney did ez şeker-sitânî

Ezon şekkersitân didem nişanhâ

Nedidem ez tu şirinter nişana 
Misâl-ı ışk peydâiyy-o pinhân

Nedidem hemçü tu peyda nihânî (Füruzan-fer, 1340).

Abdülbaki Gölpınarlı, bu on sekiz beyti şöyle şerh ediyor:

"Mevlânâ, 'Dinle, bu Ney nasıl şikayet ediyor; ayrılıkları nasıl anlatıyor' derken hem kamışlıktan kesilen Ney'i, hem de Mutlak Varlık'tan mukayyet varlığa düşen kendisini kastetmektedir. Varlık Birliği (Vahdet-i Vücud) inancına Mutlak Varlık, hiçbir kayıtla kayıtlanamaz; hiçbir sıfatla tavsif edilemez. Hatta ona 'Mutlak' demek bile onu kayıtlamaktır."(Rumi, 1973, s. 40).

Mevlânâ, neye düşen ateşin aşk ateşi, şaraba düşen coşkunluğun aşk coşkunluğu olduğunu söyleyerek aşkın, bütün âlemde bulunduğunu bildirmekte; âdeta her varlığın, istidadınca kemale doğru yüceldiğini anlatmaktadır. Mutlak Varlık'ın zuhura olan meyli, zatî iktizası, aşk ve hubb-ı zatî adlarıyla anılmıştır; bu bakımdan bütün âlem, aşktan zuhur etmiştir denebilir; soluktan soluğa da zuhur edip durmaktadır. Kâmil insanın sesi, sırrından ayrılmaz. Hz. Ali'nin buyurdukları gibi, "İnsan, dilinden anlaşılır, sözünden bilinir." Onun sesi, sözü, bir ateştir ki duyanı yakar, izafi varlığını yok eder. Bundan dolayı bu ateş kimde yoksa, yok olsun demesi, bir ilenme değil, hayır duadır; o da bu ateşe düşsün, mevhum varlığı yansın, yok olsun demektir. Buradaki şarap da şüphe yok ki bir remizdir. İnsanı varlığından, benliğinden alan; onu gerçek aşka, irfana, manevi neş'eye gark eden cezbeye işarettir. Neyin hem zehir hem panzehir olması da kâmil insanın sözüyle, bakışıyla, istidat sahibinin kötü huylarını yok etmesine, o kötü huyların zehriyle zehirlenmiş olan ilahî huylarını diriltmesine işarettir.

Mevlânâ, neyin kanlarla dolu bir yoldan bahsettiğini, Mecnun'un aşk hikâyelerini anlattığını bildirirken gerçek aşk yoluna işaret etmiş olur. Sufiler, yollarının esasını zahitliğe, riyazete, esmaya, yani Allah adlarını muayyen zamanlarda muayyen sayıda zikre dayarlar. Melamet yolunu benimseyenlerse Mevlânâ'nın;

'Riyâzat nîst pîş-i mâh eme lutfest-o bahşâyiş

Heme mihrest-o dildârî heme ayşest-o âsâyiş'2 (Rumi, 1973, s 40).

İsmail Hakkı Bursevî'ye göre, Mesnevî́nin birinci beytinin birinci mısraındaki (Ney) ile kamış kastedilmiştir. Lûgât-ı Hüsâmî'de, "Kamış Ney'dir, düdük Nây" denilmişse de bu çoğunluk itibariyledir. ${ }^{3}$ Bu beyitte "şikâyet", "hikâyet"ten evvel yazılmıştır ki

2 "Bizim katımızda riyâzât yoktur, tamamiyle lütuf vardır, tamamiyle bağış vardır; yolumuz budur bizim; tamamiyle sevgidir, gönül alıcılıktır, tamamiyle zevktir, neş'edir, düzenliktir" beytinde dediği gibi aşk ve cezbe esasına dayanırlar. Aşk, cezbeyi meydana getirir; cezbe de izafi ve mevhum varlığı kökünden yıkar, yakar, külünü havaya savurur gider. Akıl denilen seziş, anlayış, biliş ve buluş kabiliyeti, bu aşkı ne sezer, ne anlar, ne de bulur; çünkü akıl topluma, çevreye, görgüye, bilgiye, töreye ve geleneğe bağlıdır. Bunlarsa hem bilgiye, hem gerçeğe ulaşmaya engel olabilir. Akla dayanan, kendisine güvenir, bu güvenç de ona benlik, bencillik verir; aşka gelince: $O$, bütün bağları çözer; şu halde söze müşteri nasıl kulaksa, söz nasıl kulakla duyulursa, aşk da akla dayanmayan kişiye mâl olur.

3 Farsça (Na), (Nay) ve yumuşatılmış şeklinde (Ney), bilinen sazın adıdır. (Bürhan-ı Katı́ tercümesi)ne ve Lugat-ı Naci'ye göre Ney'in Davud, Şah, Mansur, Mabeyn, Nısfiye, Girift, Çığırtma, Batatl, Sipsi, Kaval gibi çeşitleri vardır. Şimdi dilimizde (Ney) daha çok kullanılıyor. 
doğrudur. Çünkü ikinci mısra, birinci mısraı açıklıyor. Bursevî́ye göre, evvelinde "B" (Bişnev) bulunması itibariyle "Besmele"ye uygun düşmektedir. Besmelesiz nâzil olan Tevbe Sûresi, "B" ile başlamaktadır. Bu "B", Besmele'nin "B"sine bedeldir ve Besmele bunun altında gizlidir ki Mesnevî̀ye Besmele ile başlanmış olduğuna işarettir. Mevlânâ Hazretleri Mesnevî'sine " $B$ " ile başlamış ve altıncı defterinde "N-nun" ile bitirmiştir. "Ben 'B'nin altında noktayım" sırrına da işaret edilmiştir. "B", başlangıca delâlet eder ki Mesnevî de böyle olmuştur. "B", ebced hesabında 'iki' sayısını gösterir. Allah ehline (Ehlullah) göre "B", Allah'ın lâtif ismi karşılığı olarak kabul edilmiştir ki Mesnevî-i şerif de ism-i lâtifinin tecellisinden doğmuştur. Bu da Mesnevî́nin, Allah'ın bir lûtfu olduğuna delâlet eder. Ruhu (lâtif) hale getirmedikçe hakikatler ve letâif âlemine girilemez. Ruh kesif cisim maddesine yakın olunca, yani ruh cesetle bulununca, kendisine de kesiflik arız olmuştur."(İsmail Hakkı Bursevi, 1287, s. 3).

Tâhirü'l-Mevlevî de Mesnevî şerhinde, kendi üstadı Mehmed Es'ad Dede Efendi'nin tamamlamaya muvaffak olamadığı Mesnevî şerhinde ilk beytlerle ilgili olarak şunları söylediğini yazar: "Neyden murad; enâniyeti, yani benliği fânî ve mertebe-i bekâ billâhda bâkî olan veliyy-i kâmil ve mürşid-i agah-dildir. Yahud, bildiğimiz Ney'dir, te'vile hâcet yoktur."(Rumi ve Tahiru'l-Mevlevî, 1963, s. 51).

Tâhiru'I-Mevlevî, “Hoca merhumun şu ifadesi bir şerh-i câmî'dir" diyor ve ekliyor;

"Zaten Ney ile insân-ı kâmil, yekdiğerinin misâli ve mümessilidir. Çünkü Ney, yetiştiği kamışlıktan kesilip ayrılmış, göğsüne ateşle delikler açılmış; başına, ğına, hatta boğumları arasına madenî halkalar ve teller takılmış, koparıldığı yerdeki rutubetten mahrum kalmış, bundan dolayı kupkuru ve sapsarı kesilmiştir. İçerisi tamamiyle boştur. Ancak, Neyzen'in nefesiyle dolar. Kendi başına kalırsa ne sesi çıkar, ne sadâsı. Vazifesi, Neyzen'in dudaklarıyla parmaklarına âlet, onun istediği nağmelerin zuhûruna vasıta olmaktır."

"İnsân-ı kâmil de böyledir. Neyistân-ı ezelden, yani (A'yân-ı sâbite) âleminden, daha açığı âlem-i ilâhideki mevkiinden kader sevkiyle şu dünyaya getirilmiş, beşeriyyet kaydına ve anâsır-ı tabiat bendine vurulmuş, ayrılık ateşile bağrı şerha şerha olmuş, makâm-ı kadîmindeki feyizden mahrum kalmış; kalbini nefsin heveslerinden, zihnini (Hesti-i mevhum) yani şu vehimden ibaret varlıktan tahliye etmiş, kendisini Allah'ın kudret ve düzenine terk etmiş, müessir-i hakîkînin iradesine vasıta olmaktan başka bir vazifesi kalmamış, nefha-i ilâhiyye hangi perdeden zuhûr eylerse o nağmeyi icrâ ediyor."(Rumi ve Tahiru'l-Mevlevî, 1963, s. 51).

\section{Ney, Âdemoğlunun Ruhunu Yansıtan Aynadır}

Çağdaş bir İranlı Mesnevî şârihi olan Kerim Zemânî de "Şerh-i Câmî-i Mesnevî-i Manevî" adlı şerhinde ilk beyti böyle yorumlamaktadır: 
"Şu Ney'in inlemelerini dinle ki ayrılıkları, firak günleri ve hicran eyyâmını hikâye ediyor; yani insanın ayrılık ve firaklarının öyküsünü hazin ve hüzünlü bir ahenkle anlatıyor: "Ney" ve Mevlânâ'nın Ney'den maksadı hakkında, "Ney"in insân-ı kâmil ve veliyy-i vâsılın ruhunu temsil ettiği söylenmelidir. "Ney" insan varlığının rumuzu olarak telâkki edildiği için Mevlânâ'dan önce de sûfiler tarafından kullanılıyordu. Bu cümleden olmak üzere Şeyh Ahmed Gazalî, risâlesinde "Ney"e işaret etmekte ve onu insanın zâtının remzi saymaktadır. Özetle Ney, kendi aslından ayrı düşmüş insanın hakikatine dâir büyük ve açık bir nişânedir. "Ney" âdeta ademoğlunun ruhunu tam anlamıyla yansıtan bir ayna gibidir."(Zemani, 1988, s. 48).

Neyin arif insanı ve insân-ı kâmili temsil ettiğinde, hemen hemen bütün Mesnevî şârihleri müttefiktirler. Abidin Paşa da Mesnevî şerhinde benzer yorumlarda bulunmaktadır:

"Ney'den maksad, ârif, âkîl (ve kâmil) insandır ki, ağzından âşıkâne mânâlı ve güzel sözler çıkar. Beyt-i şerifin ikinci mısraında ayrılıklardan şikayet eder buyurulması, insanların ve âriflerin ruh ve melekût âleminden ayrılıp dünyaya gelmelerinden şikayet etmesi demektir. Mesnevî'nin ilk beyti olan bu iki mısrada, Hazreti Celâleddin Rûmî́nin kitabında başka ibarelerle değil de "Dinle-işit" ile başlamaları, Ney'in sesinin dinlenmeye muhtaç ve (dinlemek) hassasının da diğer uzuvlardan daha faziletli olduğundandır. Kulaktan sonra başka âzânın en muteberi olan göz, yalnız mahdut bazı maddî olan şeyleri görebilir. Kulak ise varlığı hissedilmeyenleri, maneviyatı, mahlûkatı, nihayetsiz hikmetleri dinlemeye istidatlıdır." (Abidin Paşa, 1305, s. 21-22)

\section{Ney Niçin Insân-ı Kâmil'e Benzer?}

Abidin Paşa, arifin neye benzetilmesindeki münasebetleri de şöyle izah etmektedir şerhinde:

"Ney kesilmeden evvel, kamışlıkta iken daima büyür, taze hayat bulurdu. Ârifin ruhu da ruhlar âleminde iken nihayetsiz manevî lezzetlerden istifade ediyordu. Gaddar ve kuru dünyaya gelince âb-ı zülâl ve hayat kaynağı olan ruhlar âleminden mahrum olduğu için susuz kalmış kamış gibi kurumuştur.

Ney'den âşıkâne sadâlar çıkar, kâmil olan insandan da âşıkâne ve ârifâne sözler çıkar. Ney'in sesi, dinleyenlerin aşklarını artırır, ârif olan kişi de hikmet dolu sözleriyle istidatlı kimselerin aşklarını çoğaltır. Ney'in güzel âvâzından ekseriya bir hikâye, bir aşk macerası hissolunduğu gibi, ârifin sözlerinden de çok kere hakiki âşıkların halleri, lâhût âleminin sırları işitilir ve hissolunur.

Neyin boyu ile ârifin hali arasında da ilişki kurar Abidin Paşa. Ney'in boyu doğru olduğu gibi, ârifin dahi hâli doğrudur. Kamışııtan kesilen Ney, gariptir. Ruhlar âleminden ayrılan ârif de dünyada gariptir. Ney'in içi her şeyden boştur, yalnız aşk üfürüğü ile doludur. Ârif de her çeşit dedikodudan uzak, kalbi yalnız Allah'ın muhabbeti ve aşkı ile doludur. Ney, kendiliğinden âşıkâne ses çıkarmaz, üstad bir üfleyenin nefesine muhtaçtır. Ârif de zincirleme bir halde vâris olageldiği çok feyiz verici bir üfürükle yaşar." (Abidin Paşa, 1305, s. 21-22) 
Sivaslı Hacı Illyaszâde Ömer, yazmış olduğu Mesnevî Şerhi'nde, ney ile ilgili oldukça hoş ve ilginç görüşlere sahiptir. Şöyle diyor Illyaszâde:

"Dinle kamıştan, nasıl hikâye ediyor, ayrılıklardan nasıl şikayet ediyor; Allah: 'Sizin için kulağı ve gözleri ve kalbleri yarattım...' ayetinde, gözden ve kulaktan üstün gördüğü, yani dinlemeyi, görmekten ve kalb işlerinden önce andığı gibi, Hazreti Molla da dinlemeyi, Mesnevî'nin başına getirmiştir. Dinlemekle, dinleyenin kalb gözleri açıır, göğsü ferahlar. Bunun anahtarı, Allah'ın şu ayetinde buyurulmuştur: 'Dinleyiniz ve nasihat alınız.'

Kamış düdüğü sana hâl dili ile der ki: "Ben su ve toprak içinde dallarım, yapraklarım ve köklerimle yaşayıp gidiyordum. Alçak dünyanın kötülüklerinden, fitnesinden, cefasından haberim yoktu. Rahattım. Her şeyden güvenliydim. Büyüyor, serpiliyordum. Ansızın bir kaza eseri beni asıımdan, yerimden ayırdılar. Altımı, üstümü kestiler. Bağrımı deldiler. Ciğerimi binbir eziyetlerle dağladılar. En sonunda bu çektiğim zahmetler rahmet oldu. Ayrılığım kavuşmaya, vuslata çevrildi. Sonum hayroldu. Usta eline düştüm. Onunla nefes nefese geldim. Nefes arkadaşı oldum. "Rüzgârlar bile Allah'ın nefesidir" sözü, Peygamber'in hadisidir. İşte bu hadise göre o tam ve olgun adam benim kalbime kutsal nefeslerini, mutlu üfürüklerini üfledi. Hz. Meryem ilâhî nefha (üfürme) ile $\mathrm{Hz}$. İsa'ya gebe kalmıştı. Hz. İsa daha çocukken hem insanları doğru yola çağırıyor, hem de Allah'ına iyi bir kulluk yapıyordu. Ben de bir kamış parçası iken sevginin, safanın dirilik suyu, ruhu oldum. Allah'ın Hz. Meryem hakkında; 'Ben ona kendi ruhumdan üfürdüm' diye buyurduğu gibi bana da ergin adamlar üfürdüler. Doğruluk bağının bülbülü, Allah dostlarının saraylarının dâsitanı, meclislerin ruh açıcısı, şenlendiricisi oldum."(Gürtunca, 1963, s. 22-23).

Ney, işte böyle der. Buradaki neyden maksat, şârihe göre bizzat Hz. Molla (Mevlânâ) ve benzerleridir. Bazı Mesnevî nüshalarında, "Bişnev ez Ney" de bunu ispat ediyor. Burada ney ile, içleri hevâ ve hevesten, şu sözden, bu sözden ayrı, Allah'tan başka, sırdan boşaltılmış, ergin ve olgun insanlar murat edilmiştir.

Bediüzzaman Firûzanfer de Mesnevî şerhinde, şârihlerin ilk beyti yorumlarken farkIı ve çeşitli anlamlar verdiklerinden söz eder. Fakat Mevlânâ'nın neyden maksadı da Firûzanfer'e göre nefes ve üflemeyle çalınan bir saz ve kendisinin de musikişinas biri olmasıdır. "Ancak," der Firûzanfer, "Neyde bir sembolizm de vardır ve kastedilen aynı zamanda Mevlânâ'nın kendisidir. Kendini kaybetmiştir; aşk ve maşukun tasarrufu altına girmiştir. Bu maşuk, Şems-i Tebrizî, Hüsameddin Çelebi veya Allah olabilir" (Firûzanfer, 1996, s. 1-2).

Neye yüklenen bu vasıflar, aşağı yukarı benzer vasıflardır. Ortak vasıf, neyin "Innsân-ı kâmil"i temsil ediyor olmasıdır:

"Nefsânî arzulardan kurtulmuş, nefsini yok etmiş, ilâhî sevgi ile dolmuş kâmil insanın sembolüdür. Ney, kamışıktan ayrı düştüğü için inlemektedir. İnsan da, ezel âleminden, ruh âleminden dünyaya sürgün edilmiştir. Hakk'tan ayrı düştüğü için muzdariptir. Dünyada yaşadığı müddetçe acılar, hastalıklar, belalar içinde çırpın- 
dıkça insan, ruh âlemindeki mutluluğun özlemini duyacak, yabancı olduğu ve sürgün gibi yaşadığı dünyadan kurtuluş yollarını arayacaktır." (Can, t.y., s. 13)

Bazı kimselere göre de ney, aslında ayrılıktan şikâyet etmemektedir. Neyinki aslında vuslat neşesidir. Bir başka yoruma göre ise ney, bağlıı̆̆ın, sadakatin adıdır. Buna da delil, yine Mevlânâ'nın bir şiiridir:

"Notanızdaki o, tatlı konuşan kamışın sesi, şekerin tadıdır; notan gece ve gündüz bana sadâkatin (bağlıı̆ın) kokusunu getirir. Yeniden başlangıcı yap, o havaları bir kere daha çal. Varlığın aşkı, tüm sevenlerin üzerine görkemlen!

Sessiz ol, peçeni yırtma, sessiz olanların sürahisine ak, peçe ol, kendini Allah'ın (c.c.) merhametine bırak..."(Witteveen, 1997, s. 11)

\section{Aşk Ateşidir ki Neye Düştü}

Mesnevî̀nin "aşk" üzerinde yeşerdiğini ve geliştiğini belirtmiştik. Mesnevî́nin ilk on sekiz beytinde de ney ve neyin sembolize ettiği "Insân-ı Kâmil" örnek alınarak neyin, İnsân-ı Kâmil'in aşkı konu edinilmektedir. İnsân-ı Kâmil, dünyadaki nimetlerden elini ayağını çekmiş, aşkı ve yoksulluğu tercih etmiştir. "Aşk," der Hz. Mevlânâ, "Yoksulluktur, bir şeye muhtaç oluştur. Demek ki muhtaç oluş, asıldır."(Rumi, 1972, s. 103). İnsân-ı Kâmil, muhtaç olan kimsedir.

"Ateştir Ney'in bu sesi, yel değil. Kimde bu ateş yoksa, yok olsun o kişi Aşk ateşidir Ney'e düştü; aşk coşkunluğudur ki şaraba düştü."

"Mevlânâ Ney'e düşen ateşin aşk ateşi, şaraba düşen coşkunluğun aşk coşkunluğu olduğunu söyleyerek aşkın, bütün âlemde bulunduğunu bildirmekte, âdeta her varlığın, istidâdınca kemâle doğru yüceldiğini anlatmaktadır."(Rumi, 1973, s. 40)

Kerim Zemânî ise;

"Bu beyte aşkın, büyük rûhânî iksir ve münezzeh yüce kelime ile vurgulanmış olduğunu ifade etmektedir. Çoğu şârih, buna uygun olarak aşkı şerhetmişlerdir. Aşk, lûgatta 'yapışmak' anlamına gelmektedir. Bu nedenle sarmaşığa da ağaca sarılıp yapıştı̆̆ı için 'aşaka' denir. Fakat ıstılahta aşk, muhabbette ifrat demektir. Molla Kaşanî, aşkı böyle tavsif etmektedir. Azizüddin Nesefî ise aşk üzerine şunları söylemektedir: 'Aşk, sâliklerin Burak'ı ve yolcuların bineğidir. Akıl, elli yılda biriktirse de, aşk bir anda o cümleyi ateşler ve âşıkı tertemiz ve saf hale getirir. Sâlik yüz tane kırk günlük çileye girse de, âşıkın bir bakışta katettiği miktardaki seyri gerçekleştiremez."(Zemani, 1988, s. 58)

Mevlânâ'nın hayatı aşktır, demiştik. Aşk ateşi aslında neye düştüğü gibi, kendisine de düşmüştür. Aslında şu rubâîsi, ney ile kastedilenin de yine, "Cihandaki sıcaklıkların aşk ateşindendir." diyen Hz. Mevlânâ olduğunu söyleyenleri ne kadar da doğrulamaktadır:

"Bu aşk ateşi bizi pişiriyor

Ve her gece harâbât semtine çekiyor bizi

Bizi harâbât erenleriyle bir araya getiriyor

Ki onlardan başkası bizi bilmesin diye."(Rumi, 1977, s. 4) 
Tahirü'I-Mevlevî (1963), neyi söyleten müessirin hevâdan, sade bir neftsen ibaret olmadığını söylemektedir. Belki onu inleten, neyzenin hazin ve ateşîn hissiyatıdır. Bunun gibi, veliyy-i kâmili söyleten de hevâ ve heves değil, kalbinden feveran eden ve hakiki maşuktan başkasını yakıp bitiren aşktır: "Aşk bir şûledir ki, parlayınca maşuktan gayrısını yakar, mahveder." Neyin sesini, insân-ı kâmilin nefesini de layıkıyla anlayabilmek için onlardaki aşk ateşinin bir kıvılcımına olsun mazhar bulunmalıdır. Daha doğrusu, muhabbet ateşiyle yanıp kül olmalıdır. Bunun için Hz. Mevlânâ, "Aşk ateşini hâiz olmayan yok olsun." diyor. (Rumi ve Tahiru'l-Mevlevî, 1963, s. 61-62).

Kenan Rıfâî'ye (1973) göre; Erenlerin sembolü, kâmil insan Ney'in sadâsı vahiy gibi, ilham gibi ulvîdir. Onun için sıcaktır, alev gibi, ateş gibi yakıcıdır. Bu ateşi duymayan, bu ateşe değip onunla yanmayan kimse için tek çare yokluktur. Bu yokluk, maddî varlık ağlarından kurtulup, bedendeki canı aşkın eline vermek, kısaca nefsin heveslerinden, intiraslarından yok olmaktır. Ancak o zamandır ki insan, Ney sadâsının nasıı ve niçin yakıcı olduğunu anlar. Ney sadâsı ki ermişlerin sözleri ve sesleridir Kenan Rıfâî'ye göre ve insan bu sözlere kulağını tutarak onların "yok ol" demelerindeki duaların en iyisini idrâk etmelidir. Çünkü nefisten yok olmak, ilâhî birlikte var olmakla nihayetlenir. Üstün insan, baktığı her yerde, gördüğü her şeyde ilâhî hikmeti, ilâhî güzelliği gören insandır. Böyle bir güzelliği görüp de ona aşkın en yakıcı halleriyle vurgun olmamak mümkün değildir. Bunun içindir ki aşk ateşiyle yanmış ermişleri temsil eden Ney, bağrında böyle bir aşkın ateşi tutuşan sazdır (Kenan Rıfâi, t.y., s. 6).

"Eski hukemâ ve sûfilerin bazıları, aşkın bütün canlılarda görülen bir salgın olduğuna inanırlar. Çünkü kendi varlığının kemâl ve bütünlüğüne tâlib olmayan hiçbir canlı yoktur. Varlık âleminde eşyayı harekete geçiren şey, işte o kemalle beslenen aşktır." (Firûzanfer, 1996, s. 15).

Burada, Ahmet Ateş'in (1953) bu beytlerle ilgili yorumu da oldukça ilginç ve dikkate değerdir. Ahmed Ateş'e göre neyin her cemiyette inlemesi, her türlü insanlar ile düşüp kalkması da yine Mevlânâ'nın hayatı ile izah edilmelidir:

“O, her sınıftan ve her mizaçtan insanlar ile düşüp kalkıyordu. Bunlar Mevlânâ'dan istifade ediyorlar, fakat Mevlânâ'yı dinlemiyorlar, yani etrafındaki fena yaradılışIı müridler, semâ' ve raks ederken, onun gibi ilâhî aşkın cezbesine kapılmıyorlardı. (Oysa aşk Mevlânâ'ya göre, asla dönüş için duyulan iştiyaktır). Mevlânâ kendisi de, onların feryatları arasındaki sırrına kulak vermemelerinden, aşkı anlamalarından şikayet ediyor, sonra tasrih ediyor: 'Ney sesi ateştir, fakat aşk ateşidir. Bu ateşe sahip olmayanlar, yani aşkı duymayan ve binnetîce kendisini anlamayanlar, onun acılarını hissetmeyenler, sahte cezbeler ile raks ve semâ' yapanlar, mürâîler ve üstelik kendisini türlü reziletler ile ithâm edenler, yok olsun!"(Ateş, 1953). 


\section{Mevlevi Musikisi: Aşkın ve Âşıkın Müziği}

Mevlevi müziği, "aşk"ın, âşıkın müziği olmalıdır. Çünkü bir Mevlevinin beslendiği kaynak olarak kabul edebileceğimiz Mesnevî'nin özü, "aşk"tır. Mesnevî́nin yazarı, tam manasıyla bir âşıktır.

Bernard Mauguin, Mevlevi müziğini dinleyenlerin bazı maniaları aştığını, müziğin içine girdiğini ve kendisini yükseltecek olan ruhi çalışmaya müsait şartlardan istifade ettiğini; bu sebeple Mevlevi müziğinin bir yükselme vasıtası olarak kabul edilmesi gerektiğini belirtir (Mauguin, 1964). Mevlevi müziğinde düşündüren, hareketten ziyade deruni bir vecde davet eden hususiyetin varlığını, Sadeddin Nüzhet Ergün ileri sürmektedir. Sanat bakımından Türk müziğinin hiç şüphesiz en kudretli eserleri, Mevlevi ayinleridir. Ayin besteleyebilmek bir ustalık işidir ve Türk müziğinin vücuda getirilmesi en zor eserleridir (Ergün, 1942, s. 14). Mevlevilerde sadece Nâ't ve Ayin'e önem verilmiş olduğundan dolayı, ilahiler şayi olmamıştır. Mevleviler, Mesnevî ve Dîvân-ı Kebîr tefsirine kapılarak daha çok Farsça güftelere önem vermişlerdir. Mamafih, bu eserlerin güfteleri de ekseriyetle Mevlânâ Celâleddin Rûmî ve Sultan Veled'in eserleri arasından seçilmekte$\operatorname{dir}$ (Ergün, 1942, s. 14).

Hz. Mevlânâ, sonsuz bir heyecanla en yüce sevgiliye duyarlığını yalınca bir şiir ve semâ' ile sunar. Hz. Mevlânâ, şiir ve semâ' ile bütünleşir; ilahî bir kompozisyonda tekmil musiki olur. Onun neyden rebaba, defe kadar yana yakıla ifade ettiği musiki, maddi heveslerle sınırlı bir musiki anlayışı değil; ilahî aşkı, sonsuz vecdi ve heyecanı, insanın Hak katındaki duyarlığını dile getiren musikidir.

\section{Kaynakça}

Abdülhakim, H. (1991). Mevlânâ Celâleddin Rûmî. M. Şerif ve M. Armağan (Ed.), İslam düşüncesi tarihi içinde (c. 4, s. 54-55). İstanbul: İnsan Yayınları.

Abidin Paşa. (1305). Tercüme ve Şerhi Mesnevî-i Şerif. İstanbul: Dersaadet Matbaası.

Ahmet Eflâkî. (1989). Ariflerin menkıbeleri (çev. T. Yazıcı, c. 1). İstanbul: M.E.B. Yayınları.

Ateş, A. (1953). Mesnevî́nin onsekiz beytinin mânâsı. Fuad Köprülü armağanı içinde (s. 37-50). İstanbul: Osman Yalçın Matbaası.

Ayvazoğlu, B. (1989). İslam estetiği ve insan. İstanbul: Çağ Yayınları.

Brown, J. P. (1927). The darvishes or oriental spiritualism. London: Oxford University Press.

Can, Ş. (t.y.). Konularına göre açıklamalı Mesnevî tercümesi. İstanbul: Ötüken Yayınları.

Chevalier, J. (1993). Sufilik (çev. A. Kotil). İstanbul: İletişim Yayınları.

Ergün, S. N. (1942). Türk mûsikîsi antolojisi. İstanbul: İstanbul Üniversitesi Edebiyat Fakültesi Yayınları.

Fazlurrahman. (1981). İslam (çev. M. Dağ ve M. Aydın). Ankara: Selçuk Yayınları.

Firûzanfer, B. (1996). Şerh-i Mesnevî-i Şerif. Tahran: Şirket-i İntişarat-ı Illmi ve Ferhengi.

Firûzanfer, B. (1340). Külliyat-ı Şems ya Divan-ı Kebir (Vols. 1-4). Tahran: y.y.

Gazzali. (1979). İhyau ulumi'd-din (çev. Ali Arslan) (c. 10). İstanbul: Arslan Yayınları.

Gökyay, O. Ş. (1976). Risâle-i Mimâriyye. Ankara: Türk Tarih Kurumu Yayınları. 
Gölpınarlı, A. (1953). Mevlânâ'dan sonra Mevlevîlik. İstanbul: İnkilap ve Aka Kitabevi.

Gölpınarlı, A. (1963a). Mevlana: Hayatı, eserlerinden seçmeler. İstanbul: Varlık Yayınevi.

Gölpınarlı, A. (1963b). Mevlevi âdab ve erkânı. İstanbul: İnkilap ve Aka Kitabevi.

Gürtunca, M. F. (1963). Aslı Türkçe çeviri ve açıklamalarıyla Mesnevî. İstanbul: Ülkü Yayınevi.

Haeri, S. F. (1997). The element of sûfism. Elemen Books Ltd.

Haşim Bey. (t.y.). IIIm-i Edvâr. y.y

İbn Fâtik, E.-V. el-E. M. b. F. ed-D. (1106). Muhtâru'l-Hikem ve Muhâsibu'l-Kelâm. Beyrut: el-Müessesetü'lArabiyye.

İhvân-ı Safâ. (1957). Resail (Vol. 1). Beyrut: Daru's-Sadr.

İsmail Hakkı Bursevi. (1287). Şerhü'l-mesnevi (Vol. 2). İstanbul: İstanbul : Matbaa-i Âmire.

Karlığa, B. (1981). Pythagorasçı felsefenin Türk-i̇slâm felsefesi'ne yansıması. Felsefe Arkivi, 22-23, 252-254.

Kenan Rıfâi. (t. y.). Şerhli Mesnevî-i Şerif. Ankara: Hülbe Yayınları.

Lavoix, H. (1955). Histoire de la Musique. Paris: y.y.

Mauguin, B. (1964). Mevlevî müziği teksif müziği. Türk Yurdu Dergisi, 3 (11).

McKinney, H. D., \& Anderson, W. R. (1954). Music in history the evolution of an art. American Book Company.

Mehmed Ali Ayni. (1923). Intikad ve mülahazalar. İstanbul: Orhaniye Matbaası.

Nicholson, R. A. (1995). Tales of mystic meaning-selections from the Mathnawi of Jalâl-ud-Din Rûmî. Oxford: Oneworld Publications.

Nicholson, R. A. (1996). Rûmî, poet and mystic. Oxford: Oneworld Publications.

Pole, W. (1924). The philosophy of music. London: y.y.

Rice, C. (1964). The Persian sûfis. London: George Allen \& Unwin Ltd.

Rosenthal, F. (1975). The classical heritage in Islam. London: Routledge and Kegan Paul.

Rumi, M. b. M. b. H. M. C.-i. (1943). Dîvân-ı Kebîr (çev. A. Gölpınarlı, c. 1-2). İstanbul: Remzi Kitabevi.

Rumi, M. b. M. b. H. M. C.-i. (1963). Mektuplar (çev. A. Gölpınarlı). İstanbul: İnkilap ve Aka Kitabevi.

Rumi, M. b. M. b. H. M. C.-i. (1972). Fîhî Mâ Fîh, Mektuplar ve Mecalis-i Seb'a'dan seçmeler (çev. A. Gölpınarlı). İstanbul: Milli Eğitim Basımevi.

Rumi, M. b. M. b. H. M. C.-i. (1973). Mesnevi ve Şerhi (çev. A. Gölpınarlı). İstanbul: Başbakanlık Kültür Müsteşarlığı.

Rumi, M. b. M. b. H. M. C.-i. (1977). Rubâiler (çev. M. N. Gençosman, c. 2). İstanbul: M.E.B. Yayınları.

Rumi, M. b. M. b. H. M. C.-i, ve Tahiru'I-Mevlevî. (1963). Mesnevi (c. 1). Konya: Selam Yayınları.

Sipehsalar, M. F. b. A. (1312). Risâla dar Ahwâl-i Mawlana Calal ad-Din-i Mawlawi. Tahran: Çaphane-i İkbal. Sipihsalar, F. bin A.-i. (1977). Mevlânâ ve etrafındakiler (çev. T. Yazıcı). İstanbul: Tercüman 1001 Temel Eser. Sultan Veled. (1312). Ibtida-name (çev. A. Gölpınarlı). Konya: Konya Turizm Derneği.

Şehristani, E.-F. T. M. b. A. (1153). el-Milel ve'n-Nihâl (Vol. 3). Kahire: Müesseseti'l-Halebî.

Topçu, N. (1998). İslam ve insan; Mevlana ve tasavvuf. İstanbul: Dergah Yayınları.

Uludağ, S. (1992). İslam açısından mûsikî ve semâ. Bursa: Uludağ Yayınları.

Witteveen, H. J. (1997). Universal sufism. Australia: Element Books Ltd.

Yaşar, S. (1985). Mevlana: Hayatı-sanatı-tefekkürü. İstanbul: Yeni Asya Yayınları.

Yazıcı, T. (1963). Mevlânâ devrinde semâ'. Şarkiyat Mecmuası (Vol. V). 135-150.

Zemani, K. (1988). Şerh-i Câmi-i Mesnevî-i Manevî (Vol. 1). Tahran: İntişarat-ı Ittılaat. 


\title{
Philosophy of Music in Mawlawi Thought: Love, Music, and the Nay in the Masnavi
}

\author{
Yalçın Çetinkaya*
}

The Masnavi can be regarded as one of the basic books of Mawlawi literature. Accordingly, it can be said that the main dynamics that shape Mawlawism have their source in the Masnavi. In addition, it can be said that some ideas and thoughts of early Sufis before the establishment of Mawlawism affected Mawlawism. In the root of Mawlawism's view on music (or sama) there is the suggestion of early Sufis Junayd and Ruvaym of a relation between music (sama) and Bazm-i Alast. The idea that music and sama have a divine, celestial, angelic, sacred, and lofty root was affirmed by some Sufis before Mawlana. There are also some Sufi opinions which regard music as nutrient for the soul. It is possible to suggest that these ideas can be traced to earliest periods of Sufism.

One of the most important aspects of Mawlawism is love. It can be said that the Masnavi is based on divine love throughout. Accordingly, it is possible to say that like everything else in the Masnavi the Mawlawi music stems from love, and that music, in the strict sense, is the music of love.

According to Mawlana, love is one of the characteristics of the Creator. No matter who or what human beings love, this love is towards the real being. In this sense, Mawlana does not ignore the frailty of humankind, and tolerates ephemeral love since it leads human beings to the real love. Mawlana's real love is the sense of devotion to insan-I kâmil (the perfect human being) and seeing one's maturity in him. When the mood of ecstasy disappears, this love spreads all over the world, and is attached to all human beings, and even to all living beings. This love aims for benevolence, beauty, kindness, truthfulness and union. And this love is the only cure which can relieve humankind of ambition, arrogance, existence, and ego. Humankind is saved from individuality through love. In the Masnavi, the one who does not fall in love is depicted as a wingless bird. That means that the one who does not fall in love would not be able to fly in the firmament of truth, and reach that rank.

* Assist. Prof., Istanbul Technical University Turkish Music Conservatory Department of Musicology Correspondence: yalcincetinkaya60@gmail.com, Istanbul Technical University, Maçka Kampüsü, 34357 Beşiktaş, İstanbul, Turkey. 
What Mawlana and Sufis do is to extend the meaning of love to include all of creation without restricting it to religious and moral life only, and so to consider love in a universal (cosmic) way. Accordingly, Mawlana interprets the dynamism of life and history all through love. At the same time, Mawlana considers love infinite because it is a characteristic of Allah the exalted.

According to Mawlana love is freedom. If there is not love then there is no freedom, and love can exist completely only if there is freedom. Based on this, Abdulbaki Gölpınarlı explains the verses of the Masnavi related to freedom with the following: "Freedom is to be relieved of the world and hereafter, matter and meaning and to be purified from ego and selfishness". What kind of relation exists in real terms between freedom and music, especially Mawlawi music which we think of as based on love? This relation can be explained as follows: "Music made by one who is relieved of all chains and so meets freedom represents love and freedom in real terms, and it is not considerable for this music to be made for the sake of anything but Allah the exalted because humankind can only achieve freedom thanks to Him." Therefore, Mawlawi music is in real terms the music of love and freedom.

In the Muslim world, the highest interest in music largely came from the Sufis. After the late 2 nd century $\mathrm{AH}$, music has begun to prevail in tasawwuf under the name of sama, and it has become a basic characteristic of tasawwuf. Thus, sama, which is adopted by almost all Sufis and followers of Sufi paths, is seen as a feature of religion which brings humankind closer to Allah the exalted, and uplifts them. Sufis used the word "sama" instead of music (gına) because they wanted to avoid being confused with people of pleasure and ego who were highly prevalent in those times. In addition, they not only used the word sama for music, which means harmonic sound and symphonious voice, but also extended the meaning of sama including seemingly unpleasant voices due to the claim that all the voices in nature inherently contain harmony. Thus, in tasawwuf literature, sama means all the voices heard by the ear. Music is only one aspect of sama. Furthermore, some spiritual truths, secrets, hikmah (wisdom), Ru'yah, and Mushahada', which have no relation to voice, are also considered music (sama). Even silence is sama in Sufi literature.

Besides, by using the word sama and not using the words elhan and music, Sufis have tried to protect themselves from the attacks of the scholars of the Zahir (the external) who accuse them of corrupting the religion and introducing bid'ahs (innovations). In addition, they were sensitive about music and raqs (dance) (sama and wajd) so that these would not be considered play and amusement. 
Suleyman Uludağ has emphasized the necessity of taking wajd into consideration when talking about sama because, according to him, wajd is a hal that is the consequence of sama. ${ }^{2}$ Because of this, sama arouses strong feelings and love for the one who performs sama for Allah the exalted. As a result, strange hals arise, and these hals burn the heart and purify it from corruption. After this purification, one experiences "mushahada" and "mukashafa."

Sipehsalar relates that after Mawlana met Shams-ı Tabrizi, he began performing sama and turned sama into a ritual and a path. In addition, it is related that the idea of sama stems from the fact that everything in the universe rotates, and that rotation of the planets inspired Mawlana to perform the sama.

Performing the sama accompanied by harmonic voice has great influence on the lover because in these days in which the lover has stayed away from the spiritual realm, the rueful soul of the lover who is accustomed to hearing nice, spiritual voices in Bazm-i Alast, flutters, becomes enthusiastic, and brings the body into action when it hears even a little bit of the voice from Bazm-i Alast. Accordingly, everything performed by the ones who are aware of the truth during sama demonstrates a subtlety and a truth. Thus, circling refers to tawhid (unity), which is a magam (station) of Arifs (those who are aware) who can see the desired and the sought in that condition, and they get their nasib (share) from its overflow everywhere they rotate. Because of this, sama is not something that can be performed by everybody. Especially, for ordinary people it is not jaiz (permissible) but rather haram (prohibited). Sipehsalar bases that hukm (ruling) upon the claim that ordinary people are occupied with the desires of their nafs (ego). In contrast, Sama is helal (permissible) for the one who seeks Allah the exalted, and loves Him, and whose love and enthusiasm increases through sama, and who is aware of nothing but Allah the exalted.

The philosophy of music in Mawlawism is justified in the first eighteen verses of the Masnavi. In these verses, the Nay (the reed flute) is the foremost. Mawlana says that the fire of love falls on the Nay, and that the wine of truth is inflamed by love. Nothing else is both poison and antidote like the Nay, and nothing else can be a standing companion like the Nay. He says that the Nay talks about a path full of blood, and tells the stories of Mejnun. Mawlana ends these verses by saying that the crude one cannot comprehend the one who is refined, and that it is necessary to be concise.

According to early commentators what is meant here by Nay is the Insan-I Kamil (the perfect human being). It is cut from the reed of tawhid. It has left its own existence and has come to exist with the real existence. All voices made by it indicates the will of Allah the exalted; its preferences are what Allah the exalted prefers. However, in appearance it is bound by deeds and attributes. From this perspective, it longs for alem-i itlaq. Or rather that longing is an affectation, or dalliance with itself. 
Some other Sufis claim that Nay in these verses is material. For instance, according to Ismail Hakkı Bursevi, what is meant by the Nay in the first verse is the reed. While it is said that "the reed is the Nay and the pipe is the Nây" in Lugat-ı Husami, this is with respect to the majority. Abdulbaki Gölpınarlı explains those eighteen verses in this way: "Mawlana means both the Nay made of reed and himself who falls down from absolute being to bounded being as he says "Listen to the Nay, how it is complaining! It is telling about separations." According to the belief of wahdet-i wujud, absolute being cannot be bound by any boundaries, and cannot be described by any adjectives. Even using the word absolute is a restriction. Accordingly, it is possible to claim that the Nay in these verses covers both material and spiritual meanings.

Mawlana claims that love fills the whole universe by saying that the fire that covers the Nay is the fire of love, and the enthusiasm covering the wine is the enthusiasm of love. He says that all beings rise towards kemâl (perfection) according to their readiness. Mawlana says that the Nay tells of a path full of blood, and that the Nay tells the love stories of Mejnun. In this way, he refers to the path of real love.

All commentators of Masnavi accept that the Nay symbolizes insan-ı kamil and the 'arif (the one who is aware). In other words, they imply that what is meant by the Nay is mature and grown individuals who are purified of desire and lust. According to Firuzanfer, in the Masnavi, what is meant by the Nay is at the same time Mawlana himself. He is beside himself, at the disposal of love and the beloved. According to him, the beloved might be Shams-ı Tabrizi, Hüsameddin Çelebi, or Allah the exalted. According to some other commentators, the Nay does not complain about its loneliness. In fact, he is full of the joy (Nesh'a) of Wuslat. According to some other commentators, Nay implies devotion and loyalty. Therefore it is possible to say that in the first eighteen verses of the Masnavi the Nay, and the insan-i kamil it symbolizes are used as examples so that the subject is the love of the insan-i kamil. However, in order to comprehend adequately the voice of the Nay and nafas (breath) of the insan-ı kamil, it is necessary to be able to witness at least a spark of the fire of love. Indeed, it is necessary to go up in flames of love and turn into ashes. In this context, the words of Mawlana "let the ones who does not possess the flame of love become extinct" are deeply meaningful. In conclusion, it can be said that Mawlawi music is the music of love and the one who is in love, because the core of the Masnavi which we can consider as the source through which a mawlawi is nourished is love. The writer of the Masnavi is, in real terms, one who is in love. With infinite excitement Mawlana represents his sensitivity to the most sublime beloved through a plain poem and sama. Mawlana becomes one with the poem and sama, and in a divine composition this integration becomes Music. Accordingly, Mawlana's understanding of music is not an understanding bound by material desires; it is a music that expresses divine love, limitless wajd and excitement, and the sensitivity of the human being to the Real. 
